\title{
Antinociceptive Action of Nitrous Oxide Is Mediated by Stimulation of Noradrenergic Neurons in the Brainstem and Activation of $\alpha_{2 B}$ Adrenoceptors
}

\author{
Shigehito Sawamura, ${ }^{1,3}$ Wade S. Kingery, ${ }^{2,4}$ M. Frances Davies, ${ }^{1,3}$ Geeta S. Agashe, ${ }^{1,3}$ J. David Clark, ${ }^{1,3}$ \\ Brian K. Kobilka, ${ }^{5}$ Toshizaku Hashimoto, ${ }^{6}$ and Mervyn Maze ${ }^{6}$ \\ Departments of ${ }^{1}$ Anesthesia and ${ }^{2}$ Functional Restoration, Stanford University School of Medicine, Stanford, California \\ 94305, ${ }^{3}$ Anesthesiology Service and 4 Physical Medicine and Rehabilitation Service, Veterans Affairs, Palo Alto Health Care \\ System, Palo Alto, California 94304, 5 Howard Hughes Medical Institute, Stanford University, Stanford, California 94305,

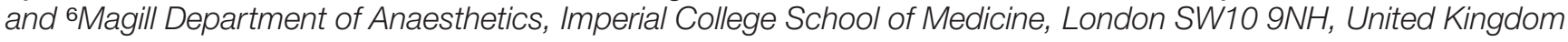

\begin{abstract}
Although nitrous oxide $\left(\mathrm{N}_{2} \mathrm{O}\right)$ has been used to facilitate surgery for $>150$ years, its molecular mechanism of action is not yet defined. Having established that $\mathrm{N}_{2} \mathrm{O}$-induced release of norepinephrine mediates the analgesic action at $\alpha_{2}$ adrenoceptors in the spinal cord, we now investigated whether activation of noradrenergic nuclei in the brainstem is responsible for this analgesic action and which $\alpha_{2}$ adrenoceptor subtype mediates this property. In rats, Fos immunoreactivity was examined in brainstem noradrenergic nuclei after exposure to nitrous oxide. After selective lesioning of noradrenergic nuclei by intracerebroventricular application of the mitochondrial toxin saporin, coupled to the antibody directed against dopamine $\beta$ hydroxylase $(\mathrm{D} \beta \mathrm{H}-$ saporin), the analgesic and sedative actions of $\mathrm{N}_{2} \mathrm{O}$ were determined. Null mice for each of the three $\alpha_{2}$ adrenoceptor subtypes $\left(\alpha_{2 \mathrm{~A}}, \alpha_{2 \mathrm{~B}}\right.$, and $\left.\alpha_{2 \mathrm{C}}\right)$, and their wild-type cohorts, were tested for their antinociceptive and sedative response to $\mathrm{N}_{2} \mathrm{O}$. Exposure to
\end{abstract}

$\mathrm{N}_{2} \mathrm{O}$ increased expression of Fos immunoreactivity in each of the pontine noradrenergic nuclei (A5, locus coeruleus, and $A 7)$. $D \beta H-$ saporin treatment eliminated nearly all of the catecholaminecontaining neurons in the pons and blocked the analgesic but not the sedative effects of $\mathrm{N}_{2} \mathrm{O}$. Null mice for the $\alpha_{2 \mathrm{~B}}$ adrenoceptor subtype exhibited a reduced or absent analgesic response to $\mathrm{N}_{2} \mathrm{O}$, but their sedative response to $\mathrm{N}_{2} \mathrm{O}$ was intact. Our results support a pivotal role for noradrenergic pontine nuclei and $\alpha_{2 \mathrm{~B}}$ adrenoceptors in the analgesic, but not the sedative effects of $\mathrm{N}_{2} \mathrm{O}$. Previously we demonstrated that the analgesic actions of $\alpha_{2}$ adrenoceptor agonists are mediated by the $\alpha_{2 \mathrm{~A}}$ subtype; taken together with these data we propose that exogenous and endogenous $\alpha_{2}$ adrenoceptor ligands activate different $\alpha_{2}$ adrenoceptor subtypes to produce their analgesic action.

Key words: nitrous oxide; locus coeruleus; noradrenergic; analgesia; anesthesia; Fos immunoreactivity
Nitrous oxide $\left(\mathrm{N}_{2} \mathrm{O}\right)$ has been used to provide anesthetic conditions suitable for the performance of surgery for $>150$ years. Because it is relatively impotent, it cannot be used as a sole anesthetic agent except when administered under hyperbaric conditions; therefore, it is most often used as an adjunctive general anesthetic agent for surgical procedures.

The state of general anesthesia encompasses a syndrome of "behaviors" including analgesia, hypnosis-sedation, amnesia, and muscle relaxation. We have investigated the mechanisms for $\mathrm{N}_{2} \mathrm{O}$ analgesic effect (it is more accurate to refer to its antinociceptive effect when studies are performed in animals who are unable to communicate the emotive experience of pain) and demonstrated that intrathecally, but not supraspinally, administered $\alpha_{2}$ antagonists could block the antinociceptive action of $\mathrm{N}_{2} \mathrm{O}$, thereby localizing the site of noradrenergic action to components within the spinal cord (Guo et al., 1996).

It is not clear whether the spinally transduced antinociceptive action of $\mathrm{N}_{2} \mathrm{O}$ originates in supraspinally located noradrenergic neurons. Noradrenergic projections to all regions of the spinal cord arise almost entirely from the dorsolateral pontine catecholamine cell groups A5, the locus coeruleus (LC), and A7. Electrical or chemical stimulation in the dorsolateral pons produces analgesic

\footnotetext{
Received June 30, 2000; revised Sept. 22, 2000; accepted Oct. 2, 2000.

This work was supported by National Institutes of Health Grant GM30232, a Veteran Affairs Merit Review, and the Medical Research Council. We thank the Clinical Investigation Facility of the $60^{\text {th }}$ Medical Group at Travis Air Force Base and especially Master Sergeant Jonathan Gorum for assisting with the hyperbaric chamber study. We also thank Prof. Lee E. Limbird for providing us with the D79N transgenic mice.

Correspondence should be addressed to Prof. Mervyn Maze, Magill Department of Anaesthetics, Chelsea and Westminster Hospital, 369 Fulham Road, London SW10 9NH, UK. E-mail: m.maze@ic.ac.uk.

Copyright (C) 2000 Society for Neuroscience $0270-6474 / 00 / 209242-10 \$ 15.00 / 0$
}

effects mediated by spinal $\alpha_{2}$ adrenoceptors that can be differentiated from cardiovascular effects, and such stimulation causes inhibition of nociceptive neurons in the deep dorsal horn (Byrum et al., 1984; Kingery et al., 1997; Willis and Westlund, 1997). We found that transection of the spinal cord eliminated the antinociceptive property of $\mathrm{N}_{2} \mathrm{O}$, suggesting that spinal pathways were involved (Zhang et al., 1999). Furthermore, exposure to $\mathrm{N}_{2} \mathrm{O}$ provoked release of norepinephrine at the level of the dorsal horn of the spinal cord, and when this neurotransmitter was depleted, $\mathrm{N}_{2} \mathrm{O}$ was no longer able to produce antinociception (Zhang et al., 1999). Therefore, we proposed that $\mathrm{N}_{2} \mathrm{O}$ could be activating a descending noradrenergic pathway, which stimulates $\alpha_{2}$ adrenoceptors in the spinal cord through the released norepinephrine. Now, using indirect measures of neuronal activation and toxins targeted for norepinephrine-containing neurons, we elucidate the role played by the noradrenergic nuclei in the brainstem for the antinociceptive action of $\mathrm{N}_{2} \mathrm{O}$.

There are three $\alpha_{2}$ adrenoceptor subtypes $\left(\alpha_{2 \mathrm{~A}}, \alpha_{2 \mathrm{~B}}\right.$, and $\left.\alpha_{2 \mathrm{C}}\right)$, and each of the genes for these receptor subtypes has been cloned (Bylund et al., 1994), thereby facilitating the creation of genetically modified reagents with dysfunctional ("point mutation") or deficient ("knock-out") subtypes. Using a moderately selective pharmacological probe in rats, as well as the D79N mouse, which has a point mutation of the $\alpha_{2 \mathrm{~A}}$ adrenoceptor gene causing its dysfunction, we showed that the $\alpha 2 \mathrm{~A}$ subtype was not responsible for the antinociceptive effect of $\mathrm{N}_{2} \mathrm{O}$ (Guo et al., 1999). Using null mice for $\alpha_{2 \mathrm{~A}}, \alpha_{2 \mathrm{~B}}$, and $\alpha_{2 \mathrm{C}}$ subtypes we now reveal the precise subtype involved in mediating the antinociceptive action of $\mathrm{N}_{2} \mathrm{O}$. This appears to differ from the mechanism involved in the antinociceptive response to exogenously administered $\alpha_{2}$ adrenergic agonists.

Surprisingly, the noradrenergic mechanisms we identify as mediators of $\mathrm{N}_{2} \mathrm{O}$ antinociception are not instrumental in the hypnotic- 
sedative action of $\mathrm{N}_{2} \mathrm{O}$ and therefore challenge the notion that the same anesthetic produces its "continuum of effects" at a single site of action.

\section{MATERIALS AND METHODS}

\section{Animals}

These experiments were reviewed and approved by our institute's Subcommittee on Animal Studies and were in accordance with the provisions of the Animal Welfare Act, the Public Health Service Guide for the Care and Use of Laboratory Animals, and Veterans Affairs Policy. All immunolesioning and immunohistochemistry experiments were performed in adult male Sprague Dawley rats (240-260 gm) from B \& K Universal (Fremont, CA). Additional behavioral studies were performed in adult $(20-30 \mathrm{gm})$ male mice. Various genetically engineered mice strains were examined, including: (1) D79N mice with a nonf unctioning $\alpha_{2}$ adrenoceptor because of a point mutation in its gene substituting aspartic acid by asparagine at amino acid residue \#79, (2) $\alpha_{2 \mathrm{~A}}-/-$ null mice with a knock-out of the $\alpha_{2 \mathrm{~A}}$ adrenoceptor gene, (3) $\alpha_{2 C}-/-$ null mice with a knock-out of the $\alpha_{2 \mathrm{C}}$ adrenoceptor gene, and (4) their wild-type (WT) controls. All these strains were on a congenic C57BL/6J background. The $\alpha_{2 \mathrm{~B}}-/-$ null mice had a knock-out of the $\alpha_{2 B}$ adrenoceptor gene on a hybrid C57BL/6J and $129 \mathrm{SvJ}$ background; as their controls we used generationally matched wild-type mice on the same hybrid background $(\mathrm{C} 57 \mathrm{BL} / 6 \mathrm{~J} \times 129 \mathrm{SvJ})$. Production of the $\alpha_{2 \mathrm{~A}}-/-, \alpha_{2 \mathrm{~B}}-/, \alpha_{2 \mathrm{C}}-/-$, and D79N mice have been described previously (Link et al., 1996; MacMillan et al., 1996; Altman et al., 1999). Rats and mice were housed in a temperature- and humidity-controlled environment and were maintained on a $12 \mathrm{hr}$ light/dark cycle. Food and water were available ad libitum.

\section{Drugs}

The anti-dopamine $\beta$-hydroxylase-saporin ( $\mathrm{D} \beta \mathrm{H}$-saporin) immunotoxin was produced by conjugating saporin, a ribosome-inactivating protein with a mouse monoclonal antibody for $\mathrm{D} \beta \mathrm{H}$ (Advanced Targeting Systems, San Diego, CA). D $\beta \mathrm{H}$, a key enzyme for the synthesis of norepinephrine, is only present in noradrenergic and adrenergic neurons. The membranebound subunit of $\mathrm{D} \beta \mathrm{H}$ is exposed during exocytotic release of norepinephrine, allowing the anti-D $\beta \mathrm{H}$ antibody to attach and to be endocytosed. When the $\mathrm{D} \beta \mathrm{H}$-saporin conjugate is injected intracerebroventricularly in rats, it is taken up in the axon terminals of catecholaminergic neurons, undergoing retrograde transport to the neuronal cell bodies where it arrests protein synthesis. This technique gradually destroys the noradrenergic neurons in the locus coeruleus and in the $\mathrm{A} 5$ and $\mathrm{A} 7$ brainstem nuclei, taking $14 \mathrm{~d}$ to complete the selective neurolytic process (Rohde and Basbaum, 1998; Martin et al., 1999). Once the neuronal cell bodies are destroyed, the lesion is permanent (Wrenn et al., 1996). The $\mathrm{D} \beta \mathrm{H}$-saporin immunotoxin was diluted in saline $(1 \mu \mathrm{g} / \mu \mathrm{l})$.

\section{Behavioral testing}

All behavioral testing was performed in a blinded manner, and the experimental groups were mixed together during each testing session to ensure identical gas exposure conditions. Using a heating blanket, the tail and paw temperatures were maintained within $0.5^{\circ} \mathrm{C}$ of $32^{\circ} \mathrm{C}$. A K-type fine wire contact thermistor (5SC-66-K-30-36) and a multimeter thermometer (HHM25; Omega, Bridgeport, NJ) were used to measure the plantar paw surface and volar tail surface temperatures for each baseline and $\mathrm{N}_{2} \mathrm{O}$ exposure nociceptive threshold test. During the $30 \mathrm{~min}$ exposure to $\mathrm{N}_{2} \mathrm{O}$, both rats and mice exhibited increased motor activity. This made tail-flick testing more difficult during $\mathrm{N}_{2} \mathrm{O}$ exposure, but using patience and care to calm the animals before testing we could confirm that the animals were withdrawing from the noxious heat stimulus during the tail-flick assay and not simply spontaneously moving their tails.

Tail-flick latencies were determined from the mean of three (in rats) or two (in mice) consecutive latencies using a tail-flick apparatus (Columbus Instruments, Columbus, $\mathrm{OH}$ ). The interstimulus interval was $\sim 60-90 \mathrm{sec}$. A high-intensity light was focused on the ventral surface of the tail, and the time for the animal to move its tail from the light beam was recorded. A different patch of the middle (rat) or distal (mice) third of the tail was exposed to the light beam each time to minimize the risk of tissue damage. The same light stimulus intensity was used for all experiments in a given strain, having been preset at an intensity that elicited a mean latency of $2.9-3.2 \mathrm{sec}$ in room air. To avoid the possibility of tissue damage, a cutoff time of $10 \mathrm{sec}$ was used; if no response had occurred by this time, a value of $10 \mathrm{sec}$ was assigned to the experimental subject. The tail-flick latency in both rats and mice was performed, whereas the animal was gently held under a towel. The animals were trained to stay under the towel, which was tented up under the investigator's hand like a cloth burrow. Latency measurements were taken only when the rat or mouse was calmly resting with tail protruding from underneath the towel.

Hot-plate latencies were determined from the mean of two consecutive latencies on a hot-plate device set at a constant $55^{\circ} \mathrm{C}$ surface temperature (Columbus Instruments). The latency was determined when the mouse first licked a hindpaw, and the cutoff time for this test was $30 \mathrm{sec}$. No mouse was used for more than one test session on the hot-plate assay, because repeated test sessions result in frequent jumping behavior, sometimes within seconds of being placed on the hot plate.
A5
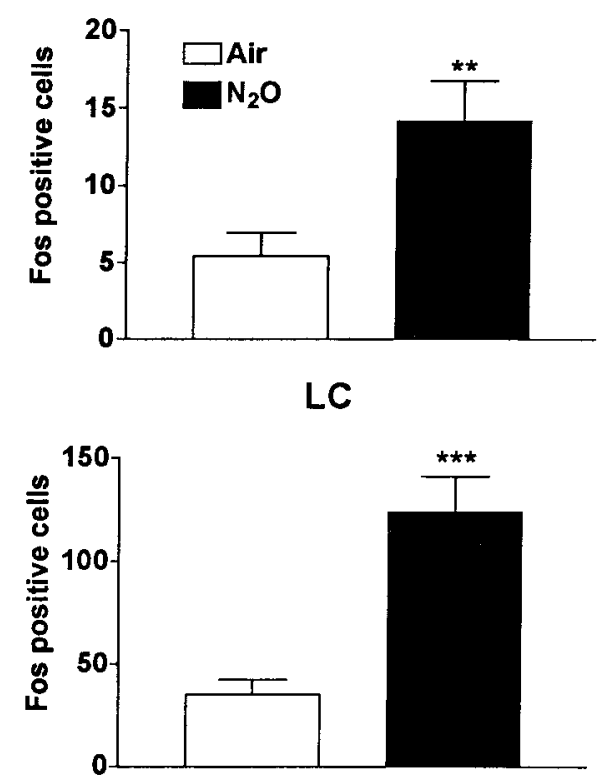

A7

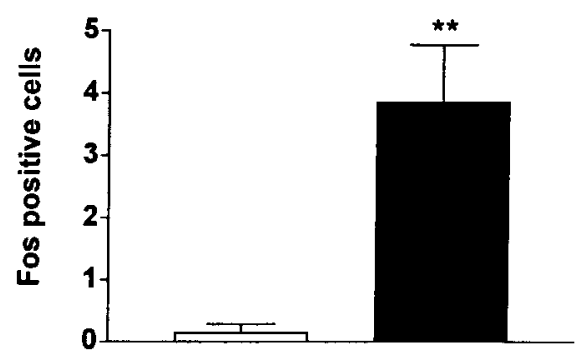

Figure 1. Effect of $\mathrm{N}_{2} \mathrm{O}$ on Fos induction in the neurons of the A5, LC, and A7 noradrenergic nuclei. Rats were exposed for $90 \mathrm{~min}$ to $70 \%$ ATA $\mathrm{N}_{2} \mathrm{O}$ $(n=7)$ or room air $(n=7)$, then transcardially perfused, and the brain was removed. Pontine sections were stained for Fos and TH. The doublestained neurons in each region were counted section by section, and the four sections with the highest counts were summed for each rat. Nitrous oxide exposure dramatically increased Fos expression in the A5 (14 \pm 3 vs $5 \pm 1$ in air), LC (124 \pm 17 vs $35 \pm 7$ in air), and A7 ( $5 \pm 1$ vs $0.1 \pm 0.1$ in air) noradrenergic neurons. ${ }^{*} p<0.01 ;{ }^{* *} p<0.001$ versus air.

The loss of righting reflex (LORR) was measured by placing the rat on its back and determining if the animal could right itself. The calculation of the $\mathrm{ED}_{50}$ for LORR was determined for each rat, based on interpolation of the gas concentrations that bracketed the righting response (Koblin et al., 1979). LORR testing was performed inside a large (3.66-m-diameter, $4.58-\mathrm{m}$-height) clinical hyperbaric chamber, with the entire Plexiglas gas exposure chamber and the investigator inside the hyperbaric chamber.

For the measurement of the sedation response, mice were placed on a rotarod (IITC; Life Sciences Instruments, Woodland Hills, CA) turning at $10 \mathrm{rpm}$ (Lakhlani et al., 1997). The mice learned to remain on the rod for $60 \mathrm{sec}$ during the course of three training sessions. Drug-naive D79N, $\alpha_{2 \mathrm{~A}}-/-, \alpha_{2 \mathrm{~B}}-/-, \alpha_{2 \mathrm{C}}-/-$ and their respective wild-type mice were indistinguishable in their ability to remain on the rod. Each mouse was tested once for its ability to remain on the rod at one of three exposure conditions [air, 35\%, and $70 \%$ atmospheres absolute (ATA) $\mathrm{N}_{2} \mathrm{O}$ ]. The cutoff time was $60 \mathrm{sec}$.

\section{Normobaric gas exposures}

Behavioral studies were performed in a Plexiglas chamber (91-cm-long, 48-cm-wide, and 38-cm-high) with a sliding door for insertion of the animals. The investigator's forearms could be inserted through two circular openings on the side of the chamber, which were sealed with rubber flap iris diaphragm air seals. The chamber was large enough to contain the tail-flick and hot-plate devices. Antinociceptive testing was always performed after 30 min $\mathrm{N}_{2} \mathrm{O}$ exposure because we had previously demonstrated a maximal antinociceptive effect in mice and rats at this time interval (Guo et al., 1999; Fender et al., 2000).

Fresh gas flow (rate varied between 3 and $101 / \mathrm{min}$ ) was introduced into the chambers via an inflow port; a fan was used to achieve adequate mixing within the chamber, and gases were purged by vacuum set to aspirate at the 

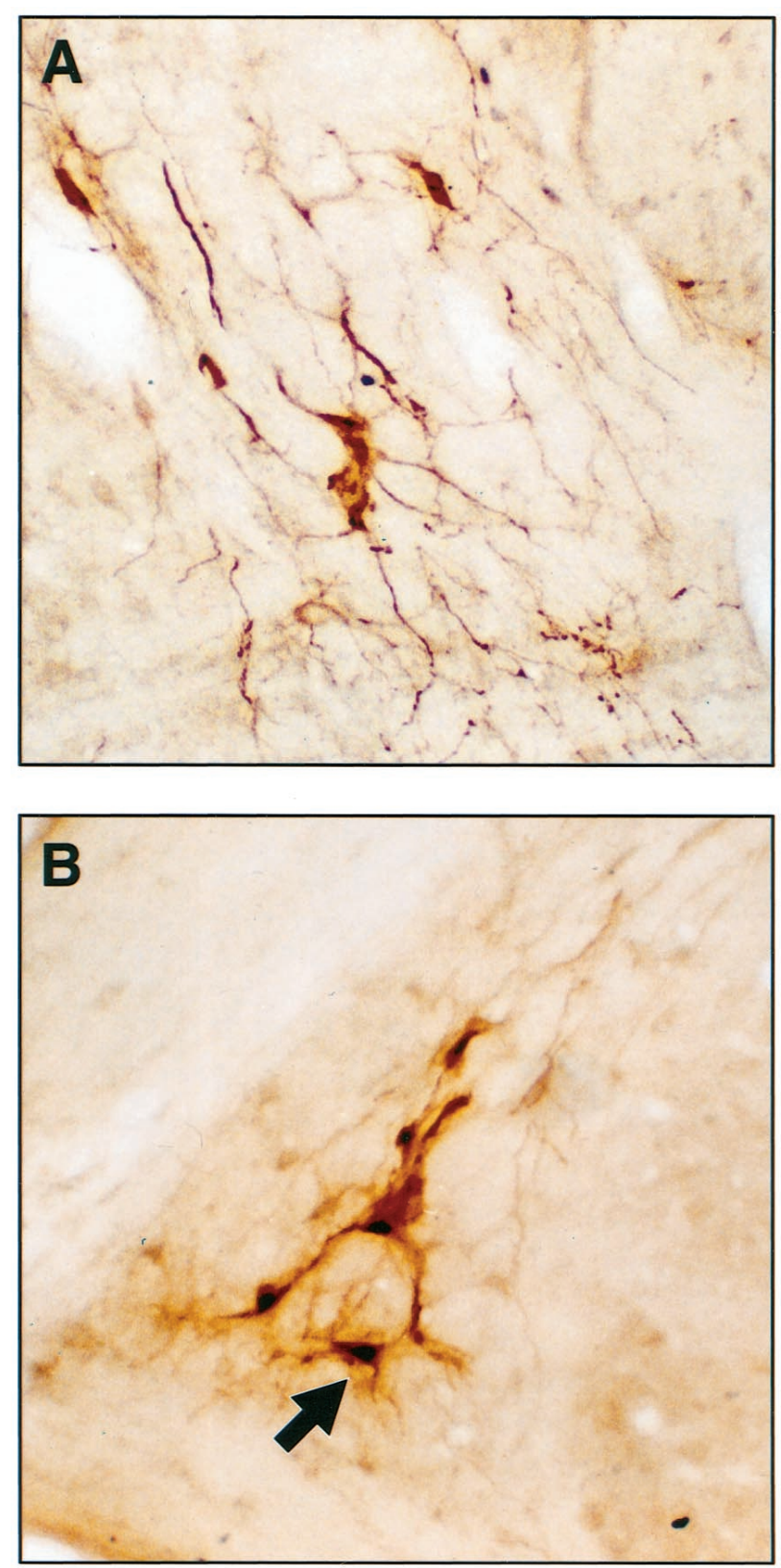

Figure 2. TH (light brown) and Fos (blue) staining in A5 neurons. A, Immunohistochemistry after exposure to air. B, Arrow points to doublestained neuron in A5 cell group of rat exposed to $\mathrm{N}_{2} \mathrm{O}$. Note the increase in double-labeled neurons with $\mathrm{N}_{2} \mathrm{O}$ exposure.

same rate as the fresh gas inflow. Oxygen concentration in the chamber was maintained between 25 and $30 \%$ ATA, and the $\mathrm{N}_{2} \mathrm{O}$ concentration was maintained at $70 \%$ ATA. Control exposure was with room air. An airway gas monitor (model 254; Datex, Helsinki, Finland) was used to continuously monitor the concentrations of $\mathrm{N}_{2} \mathrm{O}$, oxygen, and carbon dioxide in the chamber, and flow rates were adjusted to maintain the desired concentrations. Temperature in the chamber was controlled by a heating blanket, and the tail and paw temperatures were monitored before each behavioral test.

\section{Hyperbaric gas exposures}

During hyperbaric studies, the gas mix inside the gas chamber was kept at $70 \% \mathrm{v} / \mathrm{v}$ of $\mathrm{N}_{2} \mathrm{O}$ and $30 \% \mathrm{v} / \mathrm{v}$ of oxygen. The chamber pressure was increased in 0.3 atmosphere increments to generate 91,112 , and $133 \%$ ATA of $\mathrm{N}_{2} \mathrm{O}$ over a $90 \mathrm{~min}$ testing session. After a 15 min exposure at each $\mathrm{N}_{2} \mathrm{O} \%$ ATA the LORR testing was performed. Rectal temperature was monitored and maintained within $0.5^{\circ} \mathrm{C}$ of $36.5^{\circ} \mathrm{C}$ with a heating pad.

\section{Immunohistochemistry}

After 90 min exposure to $70 \%$ ATA $\mathrm{N}_{2} \mathrm{O}$, rats were anesthetized with pentobarbital $(100 \mathrm{mg} / \mathrm{kg}$, i.p.) and transcardially perfused with $100 \mathrm{ml}$ of
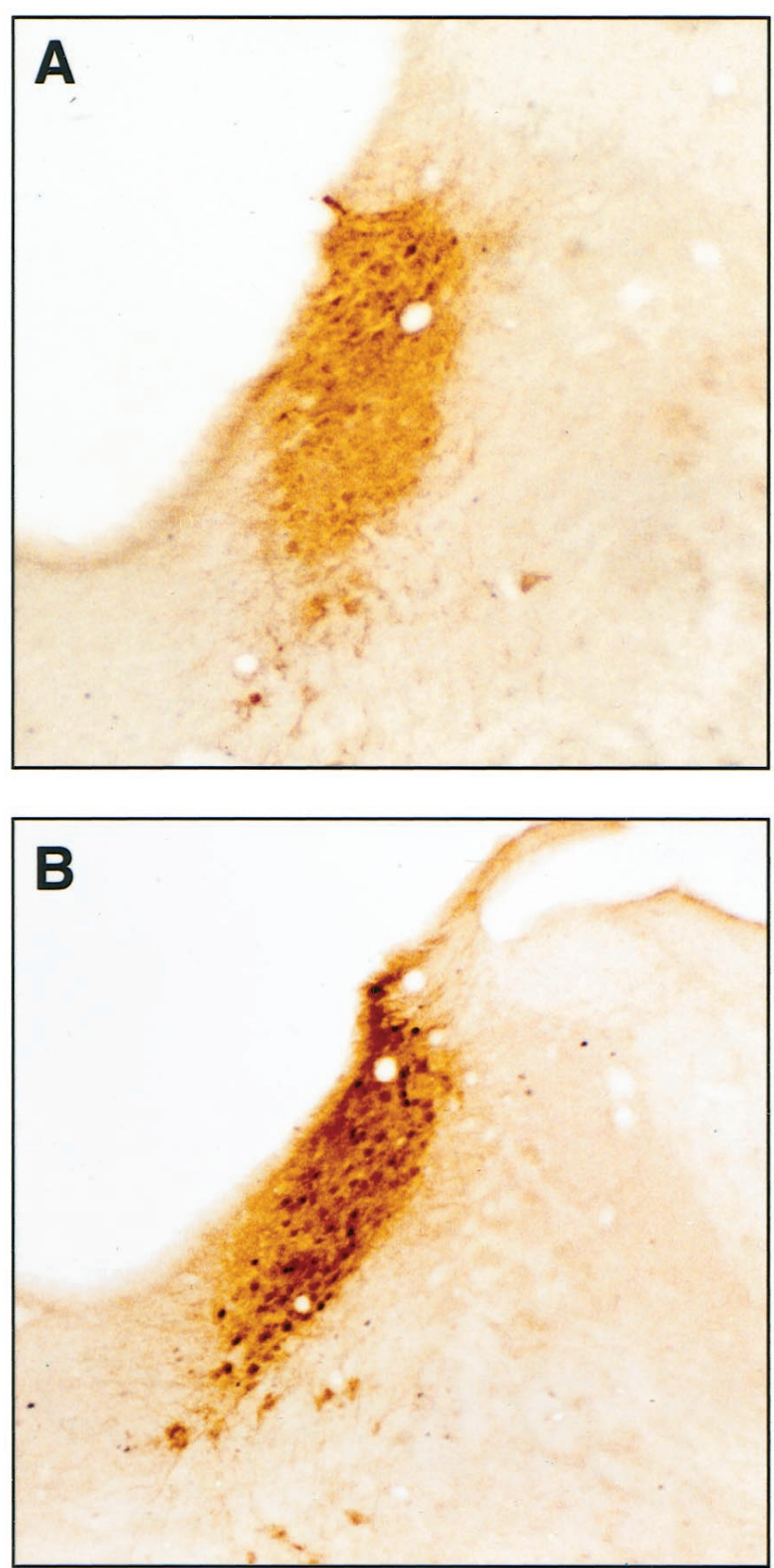

Figure 3. TH (light brown) and Fos (blue) staining in LC noradrenergic neurons. $A$, Representative section in rat exposed to air. $B$, Marked increase in double-stained neurons after $\mathrm{N}_{2} \mathrm{O}$ exposure. Also note the numerous Fos-positive nuclei in the $\mathrm{LC}$ region in TH-negative cells.

sodium PBS $0.1 \mathrm{M}$, followed by $500 \mathrm{ml}$ of paraformaldehyde $4 \%$ in sodium phosphate buffer (PB) $0.1 \mathrm{M}$. After decapitation, the whole brain was removed and submerged in the same fixative for $4 \mathrm{hr}$. Tissues were then stored in $30 \%$ sucrose solution in $0.1 \mathrm{M} \mathrm{PB}$ at $4^{\circ} \mathrm{C}$ overnight for cryoprotection. The brainstem was sliced into $40-\mu \mathrm{m}$-thick sections with a cryotome (CM1800; Leica, Heidelberg, Germany) at $-15^{\circ} \mathrm{C}$. Every third section of the brainstem (from caudal periaqueductal gray to rostral medulla) was retained and placed in the PB solution.

Sections were stained using antibodies for Fos and tyrosine hydroxylase (TH; a catecholamine-synthesizing enzyme) in sequence as follows. Sections were first incubated for $1 \mathrm{hr}$ in blocking solution (3\% normal goat serum and $0.3 \%$ Triton X-100 in PBS) and then incubated overnight with rabbit Fos antibody (1:20,000; Santa Cruz Biotechnology, Santa Cruz, CA) diluted in $1 \%$ normal goat serum and $0.3 \%$ Triton X-100 in PBS (buffer 1). After vigorous rinsing in buffer 1 , sections were incubated for $1 \mathrm{hr}$ in biotinylated goat anti-rabbit Ig (1:200; Chemicon, Temecula, CA) in buffer 1. Sections were vigorously rinsed with $0.3 \%$ Triton X-100 in 0.1 M PBS (buffer 2), then incubated for $1 \mathrm{hr}$ in avidin-biotin-peroxidase complex (Vectra Elite ABC; Vector Laboratories, Burlingame, CA) in buffer 2. Visualization of the reaction product was achieved by incubation for $4 \mathrm{~min}$ 


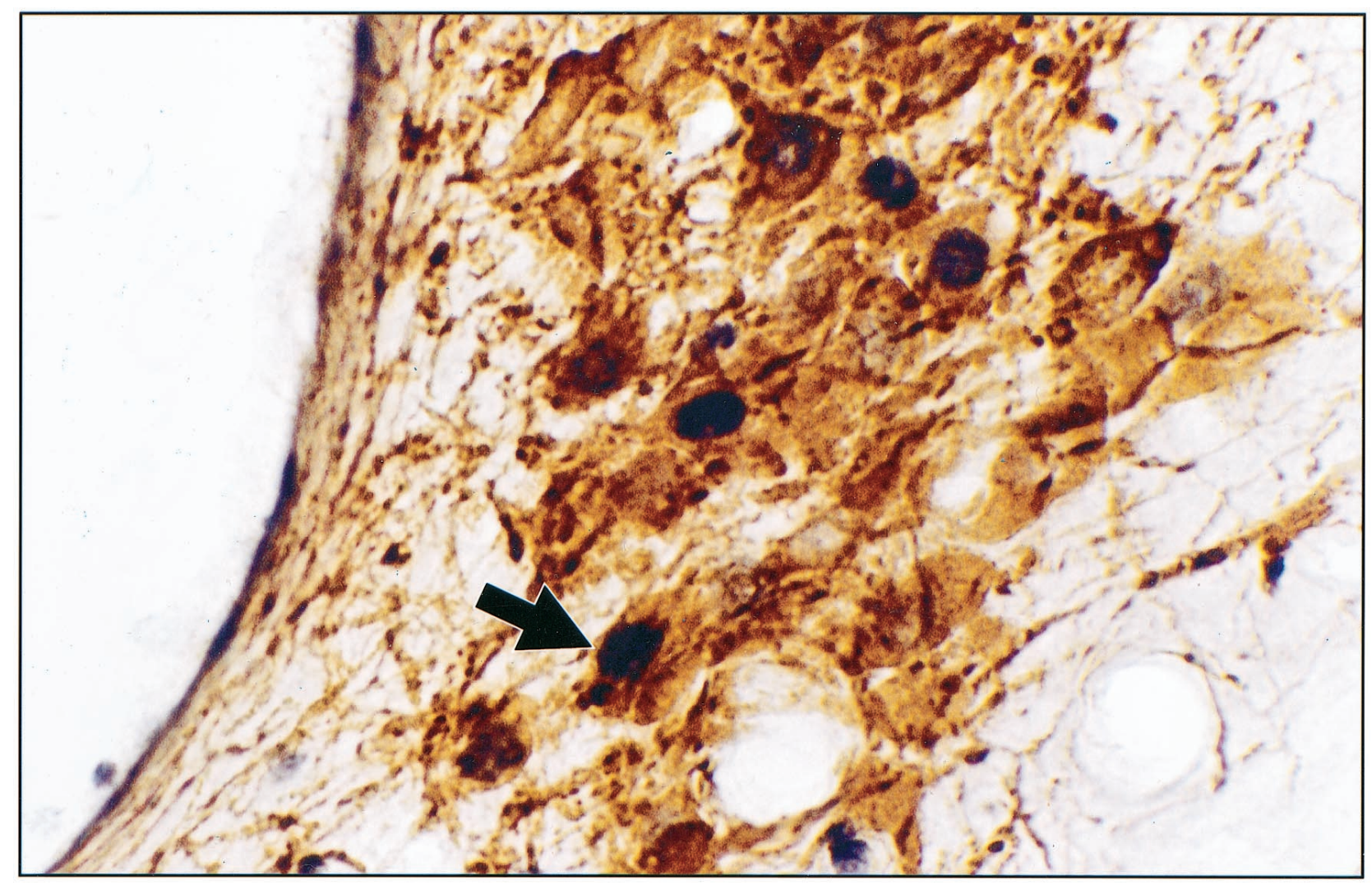

Figure 4. TH (light brown) and Fos (blue) staining in LC noradrenergic neurons. A Fos-positive nucleus is clearly seen in a TH-positive LC neuron (arrow).

with diaminobenzidine (DAB) and nickel-ammonium sulfate to which hydrogen peroxide was added (DAB kit; Vector Laboratories). Sections were rinsed in $\mathrm{PB}$ and subsequently reacted with rabbit $\mathrm{TH}$ antibody (1:50,000; Chemicon) by the same procedures as for Fos immunostaining, except that DAB reaction was performed for 2 min without nickelammonium sulfate. All the incubations were performed at room temperature. After these staining procedures, the sections were rinsed in water and placed on a slide glass. The sections were dehydrated in $100 \%$ ethanol, cleared in $100 \%$ xylene, and covered.

For those sections subjected only to TH staining, sections were exposed to rabbit TH antibody $(1: 20,000)$ and reacted with DAB-nickel solution for 4 min.

\section{Quantitation}

The sections were examined by light microscopy. The Fos-positive neurons were identified by dense black staining of the nucleus. The TH-positive neurons were identified by yellow-orange staining of the cytoplasm. The brainstem regions were located according to a rat brain atlas (Paxinos and Watson, 1986). The A5, LC, and A7 noradrenergic neurons were easily identified by $\mathrm{TH}$ staining of the cytoplasm. For each region, all the Fos-positive nuclei in TH-positive cytoplasm were counted for each section, and the four sections with the highest counts were pooled, giving a count that was the sum of all the double-stained neurons in those four sections. At the time of quantitation, the investigator performing the Fos counting was unaware of the origin of the sections.

In the $\mathrm{D} \beta \mathrm{H}$-saporin study, TH-positive neurons in the $\mathrm{A} 5, \mathrm{LC}$, and $\mathrm{A} 7$ nuclei were counted and totaled for all sections for each nucleus in each rat. Again, the investigator performing the counting was blinded as to treatment.

\section{Intracerebroventricular injections}

Rats were anesthetized with intraperitoneal injection of pentobarbital (50 $\mathrm{mg} / \mathrm{kg}$ ). While the skull was fixed in a stereotaxic apparatus, the animal was injected with $\mathrm{D} \beta \mathrm{H}$-saporin $(3 \mu \mathrm{g} / 3 \mu \mathrm{l})$ or saline $(3 \mu \mathrm{l})$ into the lateral cerebral ventricle according to coordinates obtained from Paxinos and Watson (1986) (anteroposterior, $-1.0 \mathrm{~mm}$; lateral, $-1.5 \mathrm{~mm}$ from bregma; dorsoventral, $-4.3 \mathrm{~mm}$ from skull surface) (Paxinos and Watson, 1986). The location of the injection site was confirmed in a pilot study by direct visualization of Evans blue dye injected into the lateral ventricle using these coordinates. The intracerebroventricular injections were performed with a 27 gauge needle connected via PE-20 catheter $(25-\mathrm{cm}-\mathrm{long})$ to a 10 $\mu \mathrm{l}$ Hamilton syringe that was manually injected. A small air bubble $(1 \mu \mathrm{l})$ separated the injectant from the saline-filled catheter to visualize the injection. The injection of $3 \mu \mathrm{l}$ of immunotoxin or saline was performed over $2 \mathrm{~min}$, and the needle was left in place for an additional $10 \mathrm{~min}$ after the injection to avoid reflux.

\section{$R T-P C R$}

Total RNAs were isolated from the kidney, spinal cord, and heart of the wild-type mouse (Chomczynski and Sacchi, 1987). For each sample, total RNA concentration was assessed by measuring the absorption at $260-280$ $\mathrm{nm}$ with a spectrophotometer. The quality of total RNA for each sample was examined by fractionating $10 \mathrm{mg}$ of total RNA stained with ethidium bromide in formaldehyde $/ 1 \%$ agarose gel by electrophoresis to confirm clear bands for $28 \mathrm{~s}$ and $18 \mathrm{~s}$ ribosomal RNAs. Total RNA ( $2 \mathrm{mg}$ each) from each sample was reverse-transcribed in $20 \mathrm{ml}$ of solution consisting of 2.5 $\mu \mathrm{M}$ random primer, $5 \mathrm{~mm} \mathrm{MgCl} \mathrm{m}_{2}, 1 \times$ PCR buffer, $1 \mathrm{mM}$ of dNTP, $1 \mathrm{U}$ of $\mathrm{RNase}$ inhibitor, and $2.5 \mathrm{U}$ of reverse transcriptase. The reaction conditions were $42^{\circ} \mathrm{C}$ for $15 \mathrm{~min}, 99^{\circ} \mathrm{C}$ for $5 \mathrm{~min}$, and $5^{\circ} \mathrm{C}$ for $5 \mathrm{~min}$. The products were then subjected to PCR using $15 \mu \mathrm{M}$ backward primer ${ }^{\prime} 5^{\prime} \mathrm{CTG}$ GAAGCCAAGATGTACCAGG $3^{\prime}$ ) and $15 \mu \mathrm{M}$ forward primer (5'TCATCCTCTTCACCATTTTCGG $3^{\prime}$ ) in $100 \mathrm{ml}$ of a solution consisting of $2 \mathrm{mM} \mathrm{MgCl}_{2}, 1 \times \mathrm{PCR}$ buffer, and $2.5 \mathrm{U}$ of AmpliTaq polymerase. The expected PCR product size was 466 nucleotide pairs. The PCR conditions were: 1 cycle of $95^{\circ} \mathrm{C}$ for 2 min, 35 cycles of $95^{\circ} \mathrm{C}$ for $1 \mathrm{~min}, 60^{\circ} \mathrm{C}$ for $1 \mathrm{~min}$, and $72^{\circ} \mathrm{C}$ for $30 \mathrm{sec}$, terminated by 1 cycle of $72^{\circ} \mathrm{C}$ for $7 \mathrm{~min}$. PCR products $(16 \mathrm{ml}$ each) were then fractionated by $1 \%$ agarose gel (with ethidium bromide) electrophoresis, and Polaroid pictures were taken on a UV transilluminator.

\section{Statistical analysis}

All data are presented as the mean \pm the SEM, and differences are considered significant with a $p$ value $<0.05$. The immunohistochemistry (Fos and TH staining) quantitation data were analyzed using unpaired $t$ tests. The tail-flick latencies were compared using paired (air vs $\mathrm{N}_{2} \mathrm{O}$ ) and unpaired (saline vs $\mathrm{D} \beta \mathrm{H}$-saporin) $t$ tests. The LORR $\mathrm{ED}_{50}$ values were compared between the saline and $\mathrm{D} \beta \mathrm{H}$-saporin-treated rats using the Mann-Whitney $U$ test. A one-way ANOVA was performed on the hotplate latencies when comparing groups of mice, and a $t$ test was used to test for contrasts. Figures comparing $\mathrm{N}_{2} \mathrm{O}$ analgesic effects between groups of mice or rats show the mean latency changes as the percentage of the maximum possible effect (\% MPE): \% MPE $=($ [post-gas latency - baseline latency]/[cutoff latency - baseline latency] $) \times 100$. The cutoff latencies were $10 \mathrm{sec}$ on tail-flick and $30 \mathrm{sec}$ on hot-plate. 

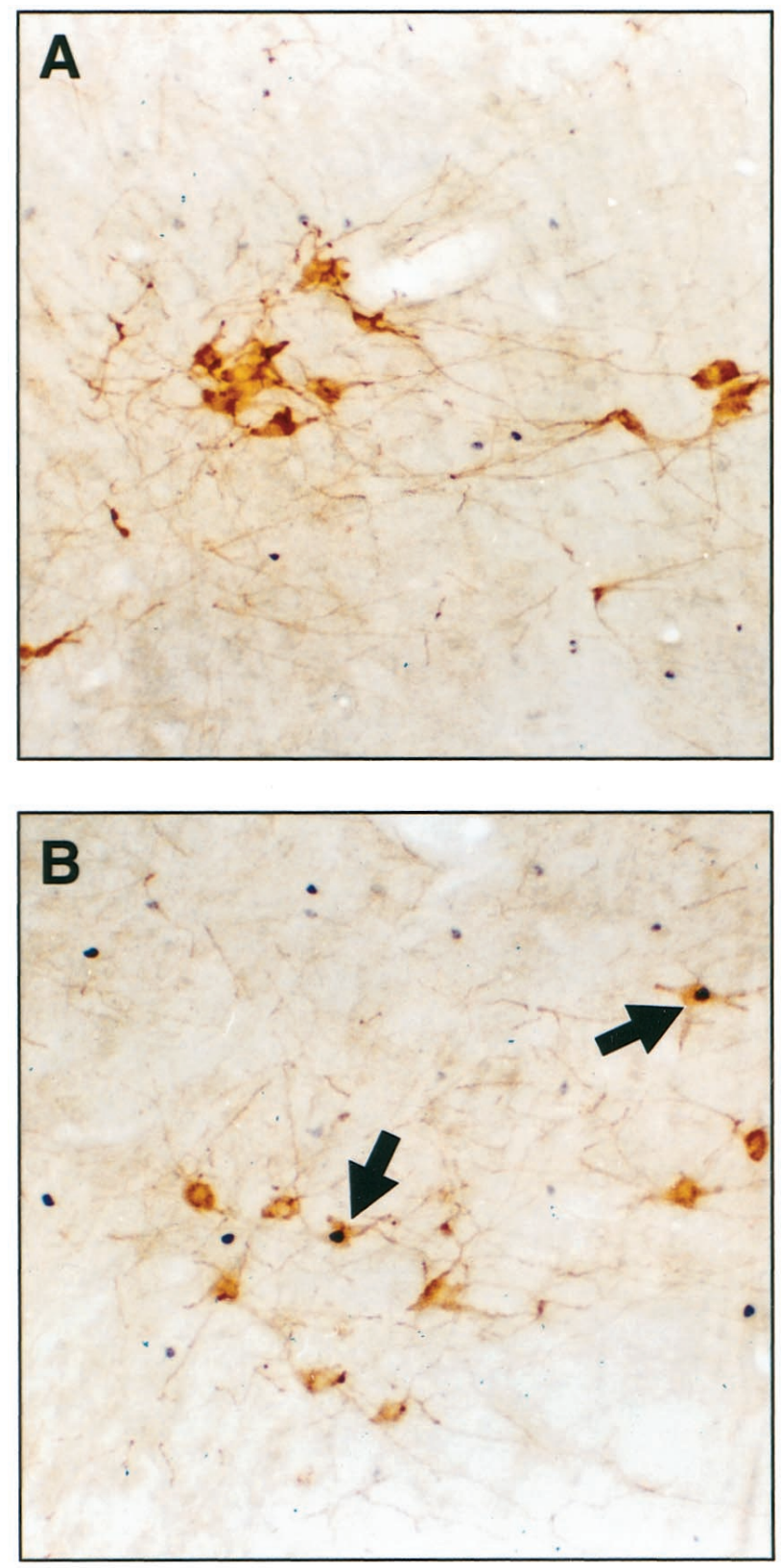

Figure 5. TH (light brown) and Fos (blue) staining in A7 sections. A, Representative section in rat exposed to air. $B$, Marked increase in doublestained neurons after $\mathrm{N}_{2} \mathrm{O}$ exposure. Also note the numerous Fos-positive nuclei in TH-negative cells.

\section{Experimental protocols}

$\mathrm{N}_{2} \mathrm{O}$ and Fos. We used Fos and TH double-staining in the brainstem to determine whether $\mathrm{N}_{2} \mathrm{O}$ exposure activated the catecholaminergic neurons in the A5, LC, and A7 nuclei. Before the Fos experiment, the rats were habituated to the experimental conditions to minimize background Fos expression induced by the stimulus of a novel environment. For 7 consecutive days the rats were taken to the laboratory and individually placed in the Plexiglas test chamber (open to room air) for $90 \mathrm{~min}$. Gas exposures of $\mathrm{N}_{2} \mathrm{O}$ or air were performed on rats individually housed in an airtight cylindrical Plexiglas chamber (20 cm in diameter, $30 \mathrm{~cm}$ in height) for 90 min.

Noradrenergic lesioning and $\mathrm{N}_{2} \mathrm{O}$ analgesia. To determine whether the noradrenergic brainstem neurons mediated $\mathrm{N}_{2} \mathrm{O}$ analgesia, $\mathrm{D} \beta \mathrm{H}$-saporin was injected to destroy the noradrenergic neurons in the brain. Rats were injected with the immunotoxin $\mathrm{D} \beta \mathrm{H}$-saporin $(3 \mu \mathrm{g} / 3 \mu \mathrm{l})$ or with saline intracerebroventricularly $(n=14$ for each group). Fifteen days after the intracerebroventricular injection, the analgesic effect of $\mathrm{N}_{2} \mathrm{O}$ was evaluated by measuring the tail-flick latency before and during $\mathrm{N}_{2} \mathrm{O}$ exposure. After the tail-flick measurement, the rat was anesthetized, and brain was harvested and single-stained for $\mathrm{TH}$ to evaluate the efficacy of noradrenergic lesioning.

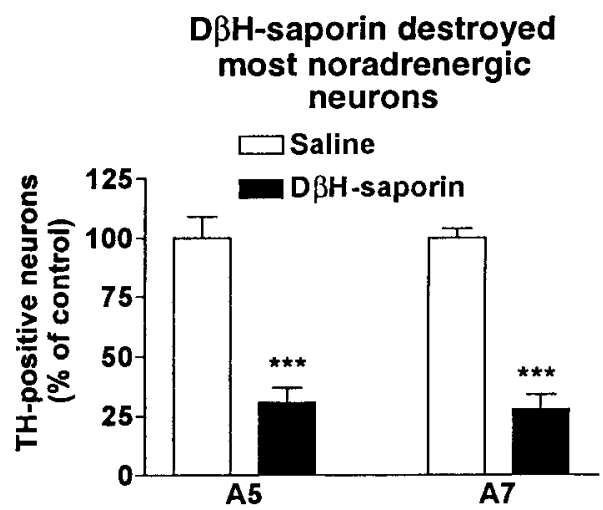

Figure 6. Immunolesioning of brainstem noradrenergic neurons with intracerebroventricular $\mathrm{D} \beta \mathrm{H}$-saporin. Rats were injected with saline $(3 \mu \mathrm{l})$ or $\mathrm{D} \beta \mathrm{H}$-saporin (3 $\mu \mathrm{g} / 3 \mu \mathrm{l} ; n=14$ for each group). Two weeks after injection the rats underwent behavioral testing and then were transcardially perfused, and the brain was removed. The brainstem sections were stained for $\mathrm{TH}$, and the number of TH-positive neurons in $\mathrm{A} 5$ and $\mathrm{A} 7$ were totaled for all sections. Data were standardized by the mean of the saline group. Approximately $30 \%$ of noradrenergic neurons survived in A5 (31 $\pm 6 \%$ ) and A7 $(28 \pm 6 \%)$ after lesioning. Counting was not performed for the LC region because TH-positive neurons are densely packed and are difficult to count in the LC. Furthermore, not a single neuron survived in LC region after $\mathrm{D} \beta \mathrm{H}$-saporin treatment. ${ }^{* * *} p<0.001$ versus saline-treated.

Noradrenergic lesioning and $\mathrm{N}_{2} \mathrm{O}$ hypnosis. We used another group of rats to determine whether the noradrenergic brainstem neurons mediated $\mathrm{N}_{2} \mathrm{O}$ hypnosis. Rats were injected with the immunotoxin $\mathrm{D} \beta \mathrm{H}$-saporin $(3 \mu \mathrm{g} / 3$ $\mu \mathrm{l})$ or with saline intracerebroventricularly $(n=14$ for each group). Fifteen days after the intracerebroventricular injection, the sedative effect of $\mathrm{N}_{2} \mathrm{O}$ was evaluated by measuring the LORR $\mathrm{ED}_{50}$ in a hyperbaric chamber.

$\mathrm{N}_{2} \mathrm{O}$ antinociception in $\alpha_{2}$ adrenoceptor subtype-deficient mice. In a pilot study we were unable to demonstrate robust $\mathrm{N}_{2} \mathrm{O}$ antinociception for the tail-flick assay in the C57BL/6J WT mice used as controls for the D79N, $\alpha_{2 \mathrm{~A}}-/-$, and $\alpha_{2 \mathrm{C}}-/-$ mice. The $\alpha_{2 \mathrm{~B}}-/-$ knock-out mice were on a different genetic background (C57BL/6J $\times 129$ SvJ hybrid); in pilot studies their genetically matched WT controls consistently exhibited significant $\mathrm{N}_{2} \mathrm{O}$ antinociception in the tail-flick assay. Therefore the antinociceptive action of $\mathrm{N}_{2} \mathrm{O}$ on tail-flick latencies was compared in the C57BL/6J $\times 129$ SvJ WT and the $\alpha_{2 \mathrm{~B}}-/-$ knock-out mice. Significant $\mathrm{N}_{2} \mathrm{O}$ antinociception was evident in the hot-plate assay in both the C57BL/6J and the C57BL/ $6 \mathrm{~J} \times 129 \mathrm{SvJ}$ WT controls. Hot-plate testing was performed in $\alpha_{2 \mathrm{~A}}-/-$, $\alpha_{2 \mathrm{~B}}-/-, \alpha_{2 \mathrm{C}}-/-$, and $\mathrm{D} 79 \mathrm{~N}$ mice, and in their respective WT controls. Baseline latencies were determined in the gas chamber under room air conditions, thereafter the mice were removed from the chamber, which was then equilibrated with the test gas mixture $\left(70 \%\right.$ ATA of $\left.\mathrm{N}_{2} \mathrm{O}\right)$. After 30 min, the mice were placed back in the gas chamber and exposed to the test gas mixture for $30 \mathrm{~min}$. The nociceptive testing was then repeated.

$\mathrm{N}_{2} \mathrm{O}$ sedation in $\alpha_{2}$ adrenoceptor subtype knock-out mice. To determine whether $\alpha_{2}$ adrenoceptor subtype contributes to $\mathrm{N}_{2} \mathrm{O}$ sedation, we used the rotarod latency assay. Rotarod testing was performed in $\alpha_{2 \mathrm{~A}}-/-, \alpha_{2 \mathrm{~B}}-/-$, $\alpha_{2 \mathrm{C}}-/-$, and D79N mice and in their respective WT controls. Baseline latencies were determined in the gas chamber under room air conditions; thereafter the mice were removed from the chamber, which was then equilibrated with the test gas mixture (either 35 or $70 \%$ ATA of $\mathrm{N}_{2} \mathrm{O}$ ). After $30 \mathrm{~min}$, the mice were placed back in the gas chamber and exposed to the test gas mixture for $30 \mathrm{~min}$. The rotarod testing was then repeated.

\section{RESULTS}

$\mathrm{N}_{2} \mathrm{O}$-activated catecholaminergic neurons in the A5, LC, and $\mathrm{A} 7$ nuclei

Rats exposed to $70 \%$ ATA of $\mathrm{N}_{2} \mathrm{O}$ exhibited a robust increase in Fos immunoreactivity in the TH-stained neurons in the A5, LC, and A7 brainstem nuclei (Fig. 1). Representative Fos staining in each noradrenergic nucleus is shown after room air or $\mathrm{N}_{2} \mathrm{O}$ exposure (Figs. 2, 3, 4, 5). These data demonstrate that $\mathrm{N}_{2} \mathrm{O}$ can activate the noradrenergic pontine cell groups that send ascending and descending projections into the brain and spinal cord, respectively (Figs. 3, 5).

\section{$\mathrm{D} \beta \mathrm{H}$-saporin treatment destroyed pontine noradrenergic neurons and blocked the analgesic but not the sedative effects of $\mathrm{N}_{2} \mathrm{O}$}

Using TH to label catecholaminergic neurons in the brainstem, we examined the effect of $\mathrm{D} \beta \mathrm{H}$-saporin immunolesioning on the 

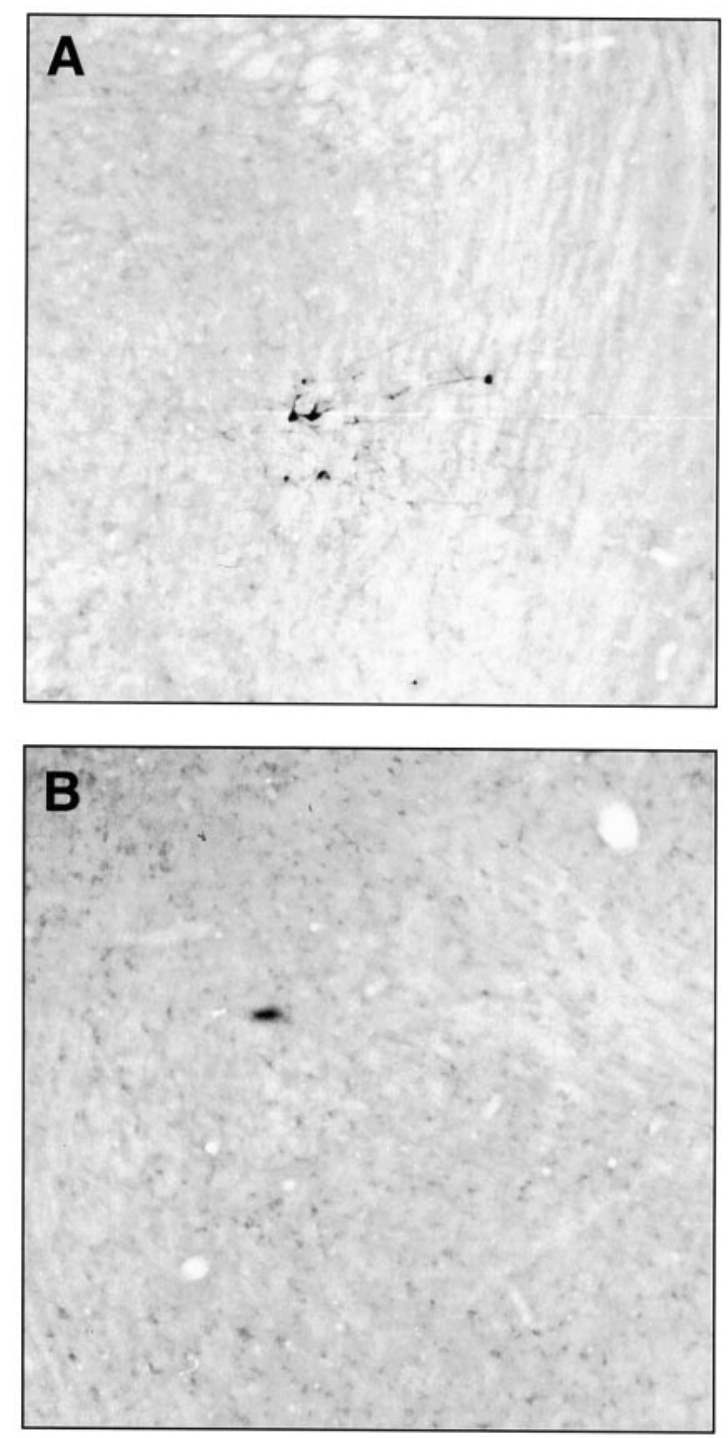

Figure 7. Immunohistochemistry of noradrenergic neurons in the A5 cell group. $A$, TH of a saline-treated rat. $B$, Profound reduction in TH-stained neurons in the immunolesioned rat.

pontine noradrenergic cell groups. After $\mathrm{D} \beta \mathrm{H}$-saporin treatment, the TH-positive noradrenergic neurons in locus coeruleus completely disappeared; however, some residual staining was observed in the A5 and the A7 noradrenergic neurons (Figs. 6, 7, 8, 9).

Whereas there was no significant difference in baseline tail-flick latencies between control and immunolesioned rats (Fig. 10 $\mathrm{A}$ ), the tail-flick latency was significantly prolonged only in control rats after $\mathrm{N}_{2} \mathrm{O}$ exposure; $\mathrm{D} \beta \mathrm{H}$-saporin-treated rats exhibited no antinociceptive response to $\mathrm{N}_{2} \mathrm{O}$. These data support the hypothesis that activation of noradrenergic pontine neurons mediates the antinociceptive response to $\mathrm{N}_{2} \mathrm{O}$.

Loss of righting reflex was used to evaluate the sedative properties of $\mathrm{N}_{2} \mathrm{O}$ in the control and immunolesioned rats. No difference was observed in the LORR $\mathrm{ED}_{50}$ values of the control and the $\mathrm{D} \beta \mathrm{H}$-saporin-treated rats, indicating that activation of these noradrenergic neurons do not mediate the sedative properties of $\mathrm{N}_{2} \mathrm{O}$ (Fig. 10B).

The $\alpha_{2 B}$ adrenoceptor subtype was required for $\mathrm{N}_{2} \mathrm{O}$ analgesia but not for $\mathrm{N}_{\mathbf{2}} \mathrm{O}$-evoked sedation

The antinociceptive effects of $\mathrm{N}_{2} \mathrm{O}$ with the hot-plate assay in the $\alpha_{2 \mathrm{~A}}-/-, \alpha_{2 \mathrm{~B}}-/-, \alpha_{2 \mathrm{C}}-/-$, and $\mathrm{D} 79 \mathrm{~N}$ mice, and in their respective WT controls are shown in Figure $11 A$. The $\mathrm{N}_{2} \mathrm{O}$ response for the hot-plate assay was reduced by $65 \%$ in the $\alpha_{2 \mathrm{~B}}-/-$ mice (vs WT
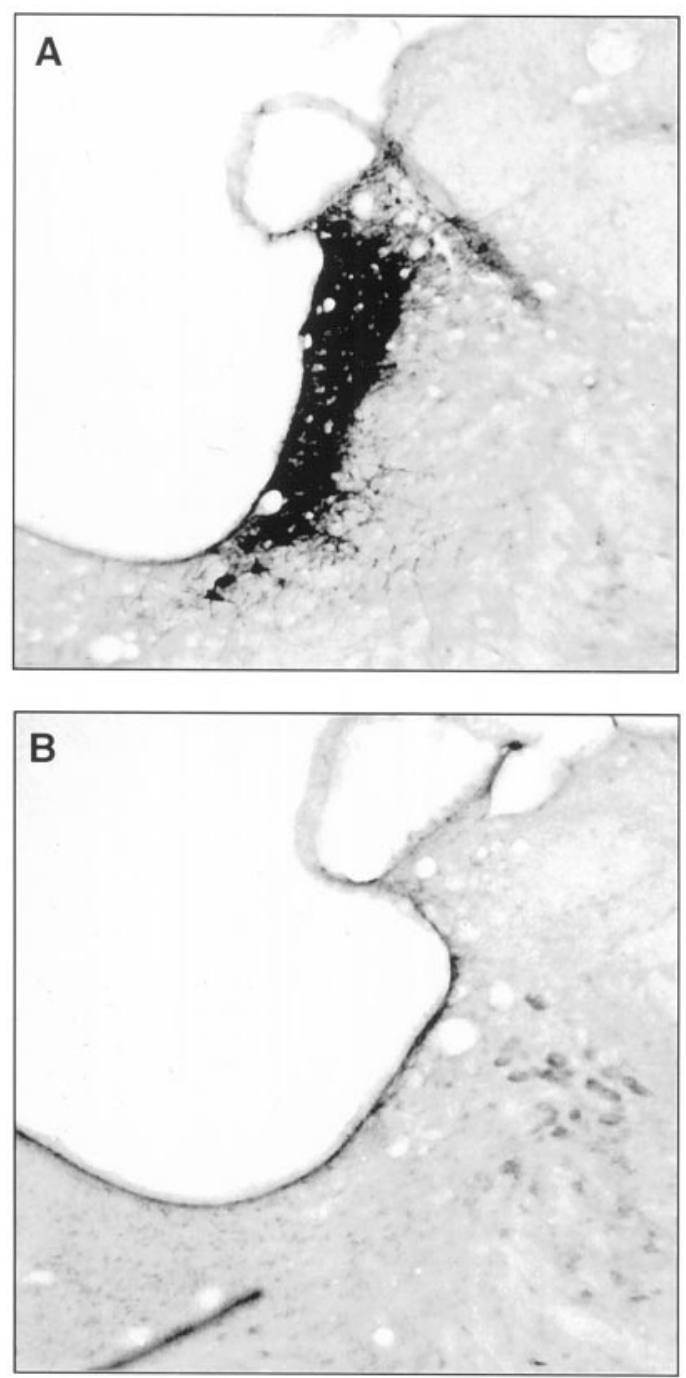

Figure 8. Immunohistochemistry of noradrenergic neurons in the LC. $A$, Very dense TH staining is observed in the $\mathrm{LC}$ region of the saline-treated rat. $B$, No immunoreactivity is observed after $\mathrm{D} \beta \mathrm{H}$-saporin treatment.

controls), suggesting that the $\alpha_{2 \mathrm{~B}}$ adrenoceptor subtype mediates $\mathrm{N}_{2} \mathrm{O}$ antinociception for this behaviorally complex hindpaw-licking response to nocifensive heat. Furthermore, $\mathrm{N}_{2} \mathrm{O}$ had no antinociceptive effect on the tail-flick assay in the $\alpha_{2 \mathrm{~B}}-/-$ mice, indicating that the $\alpha_{2 \mathrm{~B}}$ adrenoceptor subtype also mediates $\mathrm{N}_{2} \mathrm{O}$ analgesia for this nociceptive spinal reflex (Fig. 11B).

In no instance was the sedative action of $\mathrm{N}_{2} \mathrm{O}$ diminished when one of the three $\alpha_{2}$ adrenoceptor subtypes was knocked out or rendered dysf unctional (Fig. 12). Therefore, although no antinociceptive action can be elicited in $\alpha_{2 \mathrm{~B}}-/-$ mice, their response in the rotarod test is identical to that of their wild-type control mice. At the lower concentration of $\mathrm{N}_{2} \mathrm{O}$, the sedative effect of $\mathrm{N}_{2} \mathrm{O}$ appeared to be modestly enhanced in $\alpha_{2 \mathrm{C}}-/-$ mice.

\section{$\alpha_{2 B}$ adrenoceptor mRNA was present in the spinal cord of wild-type mice}

RT-PCR assays were repeated twice with kidney, spinal cord, and heart tissues from wild-type mice, and Figure 13 illustrates representative results from these assays. The RT-PCR methods used allow relative quantitation; a large $\alpha_{2 \mathrm{~B}}$ adrenoceptor mRNA signal was detected from the kidney, whereas almost none could be detected in the heart (top panel). An intermediate amount of $\alpha_{2 \mathrm{~B}}$ adrenoceptor mRNA signal was detected in the spinal cord. The bottom panel demonstrates that total RNA from each of these tissues was of similar quality and yielded the expected ribosomal bands. 

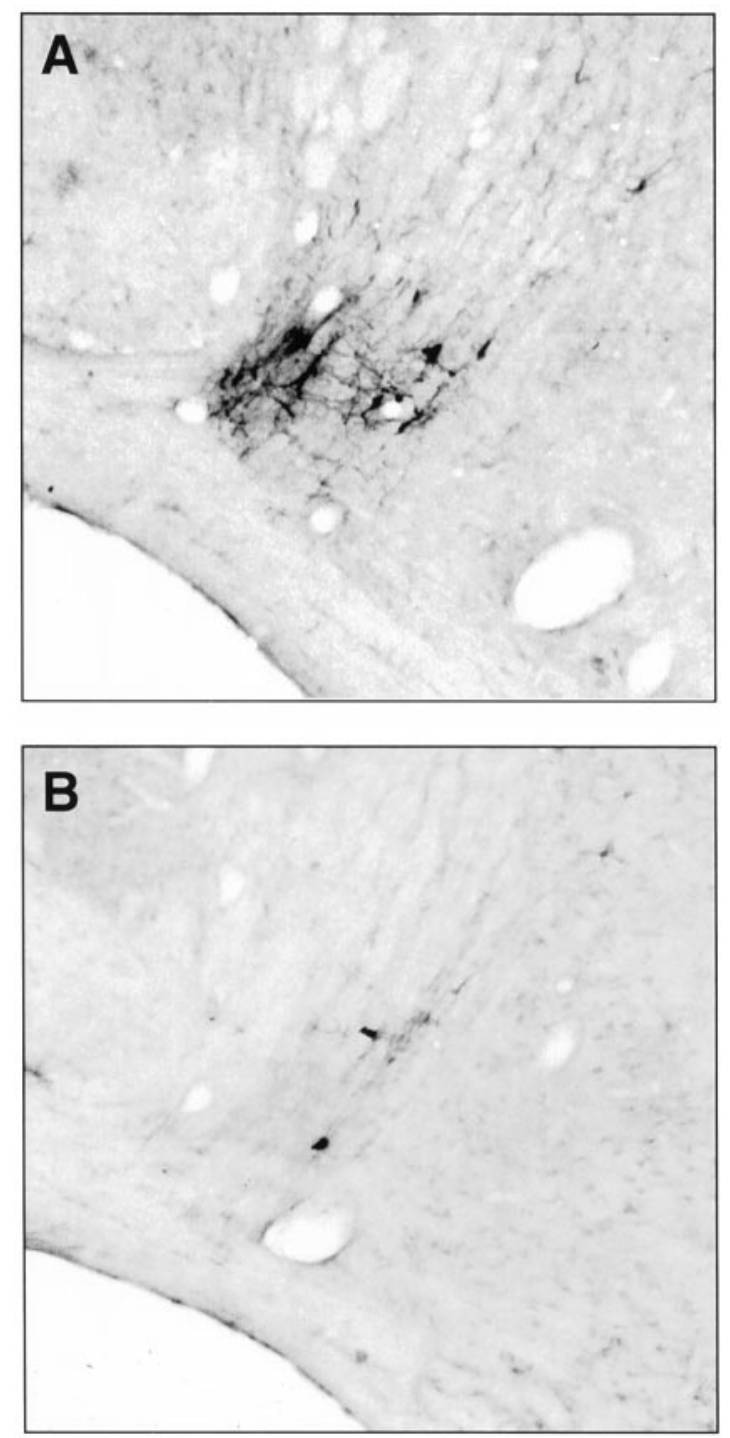

Figure 9. Immunohistochemistry of noradrenergic neurons in the A7 cell group. $A, \mathrm{TH}$ immunohistochemistry in the $\mathrm{A} 7$ cell group of a salinetreated rat. $B$, Note the absence of TH-stained neurons in the immunolesioned rat.

\section{DISCUSSION}

Exposure to $\mathrm{N}_{2} \mathrm{O}$ increased expression of Fos in TH-positive neurons in the pontine noradrenergic nuclei (A5, LC, and A7) of rats. After eliminating all of the $\mathrm{TH}$-positive neurons in the $\mathrm{LC}$ and $>70 \%$ in each of $\mathrm{A} 5$ and $\mathrm{A} 7$, the antinociceptive response to $\mathrm{N}_{2} \mathrm{O}$ was blocked. In contrast, the sedative response to $\mathrm{N}_{2} \mathrm{O}$ is maintained under these conditions. Null mice for the $\alpha_{2 \mathrm{~B}}$ adrenoceptor subtype had no $\mathrm{N}_{2} \mathrm{O}$ antinociceptive effect on tail flick and a diminished effect for the hot plate assay, whereas their WT cohorts and null mice for the other subtypes exhibited a normal antinociceptive response to $\mathrm{N}_{2} \mathrm{O}$. Normal sedative responses to $\mathrm{N}_{2} \mathrm{O}$ were evident in all the genetically modified mice.

The use of the immediate early gene product, Fos protein, as a biochemical marker of sustained neuronal activation in the brainstem catecholaminergic neurons has been validated using a wide range of stimuli (Monnikes et al., 1997; Jordan, 1998; Hahn and Bannon, 1999; Li et al., 1999). The time course of its appearance (i.e., within $60 \mathrm{~min}$ of its provocation) ideally suits its application in these experiments (Presley et al., 1990). Other investigators have demonstrated that a wide variety of anesthetic agents (although no studies involved nitrous oxide) can evoke Fos protein in discrete sites of the nervous system, including the noradrenergic (A1 and

\section{A} D $\beta \mathrm{H}-$ saporin treatment blocked
$\mathrm{N}_{2} \mathrm{O}$ antinociception

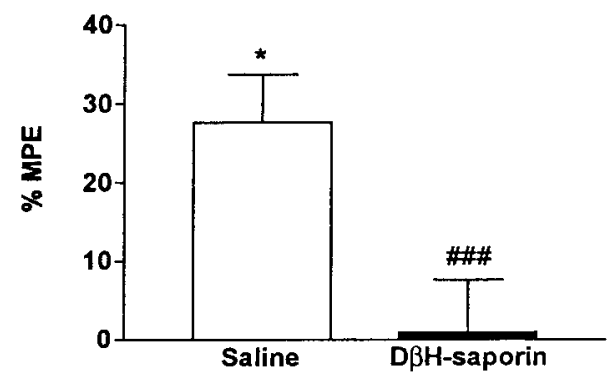
B D $3 \mathrm{H}$-saporin treatment had no
effect on $\mathrm{N}_{2} \mathrm{O}$ sedation

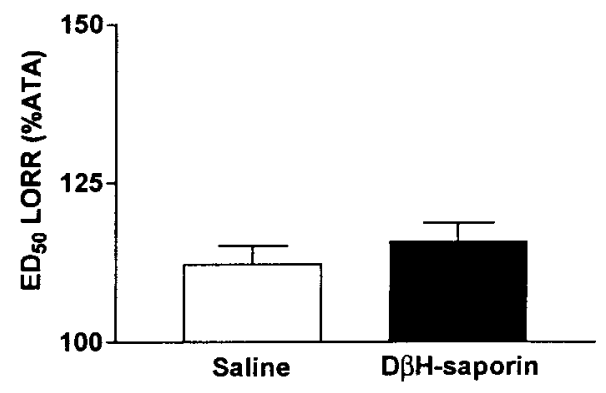

Figure 10. Effect of noradrenergic lesioning on the antinociceptive and sedative effects of nitrous oxide. A, Tail-flick latency was measured before (air) and after $\mathrm{N}_{2} \mathrm{O}$ exposure. There was no significant difference in baseline latencies of the saline $(n=11)$ - and $\mathrm{D} \beta \mathrm{H}$-saporin $(n=12)$-treated rats, using the same intensity setting for the radiant heat source. The $\mathrm{N}_{2} \mathrm{O}$ antinociceptive effect was observed in the saline treatment group $\left(27.7^{2} \pm\right.$ $6.1 \% \mathrm{MPE})$, but not in the $\mathrm{D} \beta \mathrm{H}$-saporin-treated rats $(1.0 \pm 6.7 \% \mathrm{MPE})$. Three rats in the control group and two rats in the LC lesion group were excluded from the tail-flick data because of an excessive change in tail temperature after $\mathrm{N}_{2} \mathrm{O}$ exposure. $B$, There was no difference between saline $(n=10 ; 112 \pm 3 \%)$ - and $\mathrm{D} \beta \mathrm{H}$-saporin $(n=10 ; 116 \pm 3 \%)$-treated rats in the sedative effect of $\mathrm{N}_{2} \mathrm{O}$, as measured by the concentration (ATA), which prevented a righting reflex in half the rats $\left(\mathrm{ED}_{50} \mathrm{LORR}\right) .{ }^{*} p<0.05$ versus

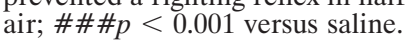

A2) and adrenergic (C1) medullary nuclei (Krukoff et al., 1992; Miura et al., 1994; Takayama et al., 1994; Clement et al., 1998). Significantly, none of these previous studies have observed anesthetic evoked Fos expression in the pontine noradrenergic nuclei (A5, LC, and A7). Whereas we have shown that $\mathrm{N}_{2} \mathrm{O}$ activates pontine noradrenergic neurons, the mechanism by which this occurs has not been established. At the ion channel level, $\mathrm{N}_{2} \mathrm{O}$ is known to block NMDA channels (Jevtovic-Todorovic et al., 1998), which would tend to reduce cell excitability; however, its possible role in the activation of noradrenergic neurons has not been addressed.

Saporin is a ribosome inactivating protein that ultimately results in cell death and destruction. By coupling this toxin to an antibody directed against a key synthetic enzyme, we are able to selectively destroy only those neurons containing this enzyme (Wrenn et al., 1996). Because dopamine- $\beta$-hydroxylase only exists in noradrenergic or adrenergic neurons, only these cells will be selectively destroyed (Martin et al., 1999). In this manner we have isolated the role of activation of noradrenergic pathways in the behavioral responses to $\mathrm{N}_{2} \mathrm{O}$. Whereas activation of noradrenergic pathways is causally linked to the antinociceptive action of $\mathrm{N}_{2} \mathrm{O}$, it does not appear to play any role in the sedative response to $\mathrm{N}_{2} \mathrm{O}$.

The processes whereby activation of noradrenergic pathways produce antinociception in rodents has been investigated by our laboratory. Previously, we have shown that descending noradrenergic pathways are a pivotal component in the antinociceptive response to $\mathrm{N}_{2} \mathrm{O}$ because both spinal cord transection as well as depletion of norepinephrine in the spinal cord will prevent this 

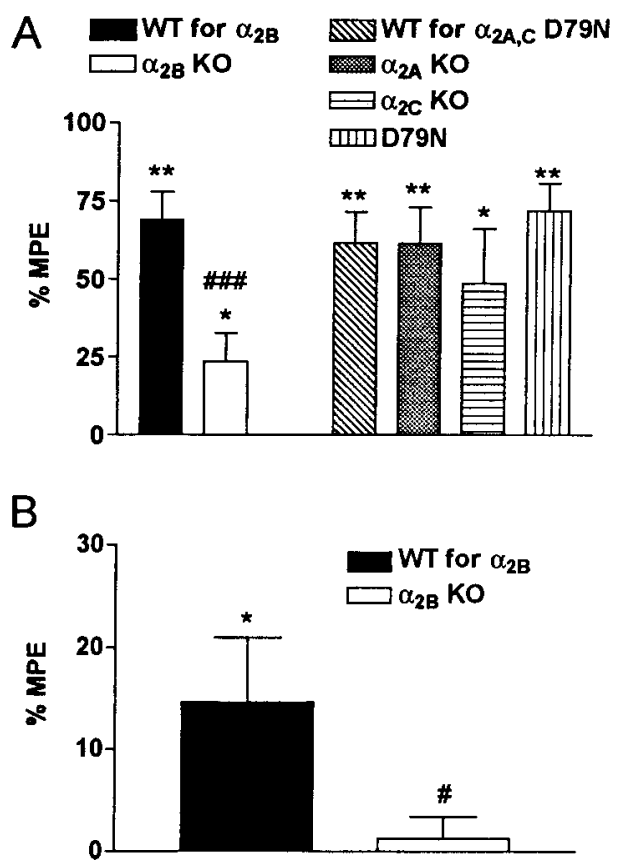

Figure 11. $A, \mathrm{~N}_{2} \mathrm{O}$ antinociceptive effect on hot-plate assay was reduced in $\alpha_{2 \mathrm{~B}} \mathrm{KO}$. This figure illustrates the antinociceptive effects of $\mathrm{N}_{2} \mathrm{O}$ on the hot-plate assay in the $\alpha_{2 \mathrm{~A}}-/-, \alpha_{2 \mathrm{C}}-/-$ knock-out mice $\left(\alpha_{2 \mathrm{~A}} \mathrm{KO}\right.$ and $\alpha_{2 \mathrm{KO}} \mathrm{K}$ ), the D79N mutant mice with nonf unctional $\alpha_{2}$ adrenoceptors, and in their genetically matched WT controls (on a C57BL/6J congenic background). The $\alpha_{2 \mathrm{~B}}-/-\left(\alpha_{2 \mathrm{~B}} \mathrm{KO}\right)$ mice were on a different genetic background $(\mathrm{C} 57 \mathrm{BL} / 6 \mathrm{~J} \times 129 \mathrm{SvJ}$ hybrid), so they required their own genetically matched WT controls (WT for $\alpha_{2 \mathrm{~B}}$ ). There were no differences in baseline hot-plate latencies between the various mouse strains (data not shown). Only the $\alpha_{2 \mathrm{~B}} \mathrm{KO}$ mice had reduced $\mathrm{N}_{2} \mathrm{O}$ antinociception on the hot-plate assay (reduced $65 \%, 24 \pm 9$ vs $69 \pm 9 \% \mathrm{MPE}$ in WT for $\alpha_{2 \mathrm{~B}}$ ), indicating that the $\alpha_{2 \mathrm{~B}}$ adrenoceptor subtype mediates $\mathrm{N}_{2} \mathrm{O}$ antinociception for this supraspinal response. The $\mathrm{N}_{2} \mathrm{O}$ antinociceptive responses (\%MPE) in the other knock-out and mutant mouse strains were: WT, $62 \pm 10 ; \alpha_{2} \mathrm{KO}$, $62 \pm 11 ; \alpha_{2 \mathrm{C}} \mathrm{KO}, 49 \pm 18$; and D79N, $72 \pm 9(n=16$ for each group $) . B$, $\mathrm{N}_{2} \mathrm{O}$ antinociceptive effect on tail-flick assay was lost in $\alpha_{2 \mathrm{~B}} \mathrm{KO}$. There were no differences in baseline tail-flick latencies of the $\alpha_{2 \mathrm{~B}} \mathrm{KO}$ mice and their WT controls. The WT for $\alpha_{2 B}$ mice had a significant $\mathrm{N}_{2} \mathrm{O}$ antinociceptive effect on the tail-flick assay $(14.7 \pm 6.2 \% \mathrm{MPE})$, but the $\alpha_{2 \mathrm{~B}} \mathrm{KO}$ mice had no $\mathrm{N}_{2} \mathrm{O}$ antinociceptive response on the tail-flick assay $(1.3 \pm 2.1 \% \mathrm{MPE})$, indicating that the $\alpha_{2 \mathrm{~B}}$ adrenoceptor subtype mediates $\mathrm{N}_{2} \mathrm{O}$ antinociception $\left(n=10\right.$ for each group). $\mathrm{N}_{2} \mathrm{O}$ had no effect on tail-flick latencies in the C57BL/6J WT controls for the D79N, $\alpha_{2 \mathrm{~A}} \mathrm{KO}$ and $\alpha_{2 \mathrm{C}} \mathrm{KO}$ mice, so these strains were not tested for $\mathrm{N}_{2} \mathrm{O}$ tail-flick effects. ${ }^{*} p<0.05 ;{ }^{*} p<0.01$ versus air; \#p $<0.05$; \#\#\#p $<0.001$ versus genetically matched WT controls.

behavioral response (Zhang et al., 1999). Furthermore, $\mathrm{N}_{2} \mathrm{O}$ provokes release of spinal norepinephrine over the same time course as it produces its antinociceptive action and intrathecal administration of an $\alpha_{2}$ antagonist blocks $\mathrm{N}_{2} \mathrm{O}$ evoked antinociception (Guo et al., 1996). Collectively, these data indicate that $\mathrm{N}_{2} \mathrm{O}$ can stimulate noradrenergic bulbospinal neurons, resulting in spinal norepinephrine release and activation of dorsal horn $\alpha_{2}$ adrenoceptors, thus inducing antinociception (Kingery et al., 1997).

Norepinephrine is a nonselective agonist at adrenergic receptors. Intrathecal administration of a selective $\alpha_{2}$ antagonist (atipamezole) blocked the $\mathrm{N}_{2} \mathrm{O}$ antinociceptive response (Guo et al., 1996), suggesting this class of spinal adrenoceptors mediates the action. Earlier studies had revealed that spinal $\alpha_{2}$ adrenoceptors are capable of transducing antinociception from supraspinal activation (Jones, 1991; West et al., 1993; Willis and Westlund, 1997). Yet prazosin, a prototypic $\alpha_{1}$ antagonist, also blocked the antinociceptive response to $\mathrm{N}_{2} \mathrm{O}$ (Guo et al., 1999). This effect may be because of its ability to block $\alpha_{2 \mathrm{~B}}$ and $\alpha_{2 \mathrm{C}}$ adrenoceptors, although it has no activity at the $\alpha_{2 \mathrm{~A}}$ subtype (MacDonald and Scheinin, $1995)$. Further corroboration that the $\alpha_{2 \mathrm{~A}}$ adrenoceptor subtype is not involved was provided by data from studies in which the D79N transgenic animals, which have dysfunctional $\alpha_{2 \mathrm{~A}}$ adrenoceptor subtypes, exhibit dose-dependent antinociception in response to

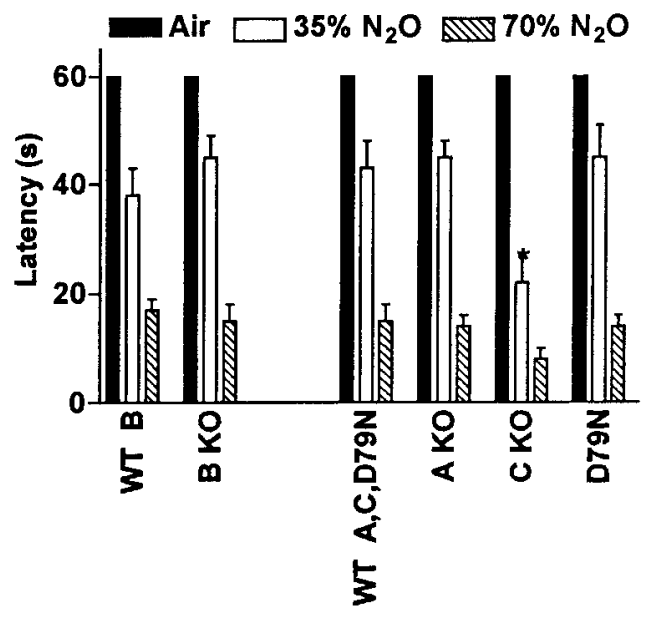

Figure 12. $\quad \mathrm{N}_{2} \mathrm{O}$ sedative effect was intact in the $\alpha_{2 \mathrm{~B}}-/-$ knock-out mice. The sedative effects of $\mathrm{N}_{2} \mathrm{O}$ (35 and 70\% ATA) in the $\alpha_{2 \mathrm{~A}}-/-, \alpha_{2 \mathrm{~B}}-/-$, and $\alpha_{2 C}-1-$ knock-out mice ( $A K O, B K O$, and $C K O$, respectively), the D79N mice, and in their respective WT controls ( $n=8$ for each group). There were no differences in baseline rotarod latencies among the various mouse strains. The sedative effect was observed on the rotarod assay in all the mouse strains including the B KO mice. An enhanced sedative effect was observed in the $\mathrm{C} \mathrm{KO}$ mice with the lower concentration of $\mathrm{N}_{2} \mathrm{O} .{ }^{*} p<$ 0.05 versus air.

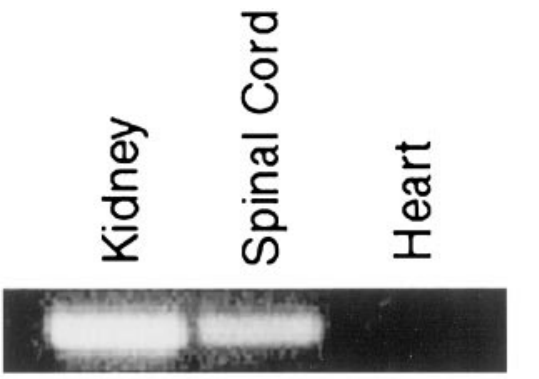

$466 \mathrm{bp}$

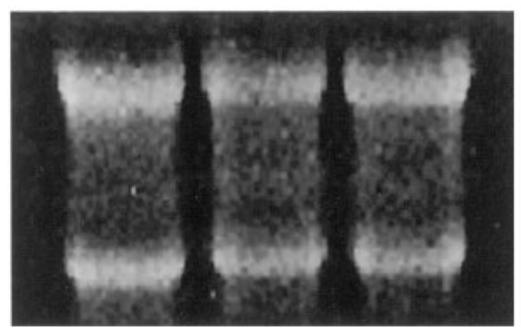

$28 \mathrm{~S}$

Figure 13. Detection of mRNA for $\alpha_{2 \mathrm{~B}}$ adrenoceptor in various tissues from wild-type mice $(n=2)$. RT-PCR analysis of total RNA prepared from kidney, spinal cord, and heart tissue revealed detectable levels of message for this receptor were found in the kidney and spinal cord but not in heart tissue. The bottom panel demonstrates that total RNA from each of these tissues was of similar quality and yielded the expected ribosomal bands after ethidium staining.

$\mathrm{N}_{2} \mathrm{O}$ exposure (Guo et al., 1999). Now we report that mice deficient in either the $\alpha_{2 \mathrm{~A}}$ or the $\alpha_{2 \mathrm{C}}$ adrenoceptor subtype respond normally to $\mathrm{N}_{2} \mathrm{O}$. However, mice that are deficient in the $\alpha_{2 \mathrm{~B}}$ adrenoceptor subtype exhibit little (Fig. 11A) or no (Fig. 11B) antinociceptive effect. The quantitative difference in these two assays may relate to the fact that the tail-flick assay measures pain processing in the spinal cord, exclusively; supraspinal events may impact on the hot-plate test. Therefore, these data suggest that the $\alpha_{2 \mathrm{~B}}$ adrenoceptor mediates the antinociceptive response to the endogenously released norepinephrine in the dorsal horn of the spinal cord, which we have shown to contain message for $\alpha_{2 \mathrm{~B}}$ subtype.

Much of the earlier pharmacological evidence pointed to activation of $\alpha_{2 \mathrm{~A}}$ subtype for $\alpha_{2}$ adrenoceptor-mediated antinociception (Millan, 1992; Millan et al., 1994). However, a prazosin-sensitive $\alpha_{2}$ 
adrenoceptor subtype was shown to inhibit release of substance $\mathrm{P}$ in a spinal cord preparations, suggesting a role for the $\alpha_{2 \mathrm{~B}}$ or $\alpha_{2 \mathrm{C}}$ adrenoceptor subtypes in antinociception (Ono et al., 1991). Furthermore, ST-91, a non- $\alpha_{2 \mathrm{~A}}$ subtype-preferring $\alpha_{2}$ agonist, was shown to induce antinociception in rats when it was administered intrathecally, and again this effect was blocked by prazosin (Graham et al., 1997, 2000; Takano et al., 1992a; Takano and Yaksh, 1992b). Inability to reconcile these disparate findings highlights the difficulties involved in using pharmacological approaches, especially when these probes lack subtype selectivity. The development of genetically modified reagents has facilitated subtype-specific approaches. Studies using D79N mice, in which the gene for $\alpha_{2 \mathrm{~A}}$ adrenoceptor subtype has been mutated rendering the expressed protein dysf unctional, established a role for the $\alpha_{2 \mathrm{~A}}$ subtype for the thermal analgesic response to the potent $\alpha_{2}$ adrenoceptor agonist dexmedetomidine (Hunter et al., 1997; Lakhlani et al., 1997). However, the D79N mice do exhibit some residual $\alpha_{2}$ adrenoceptor agonist-induced effects on spinal analgesia in the intrathecal substance P-induced pain model (Stone et al., 1997) and for tail-flick analgesia after the administration of the $\alpha_{2}$ agonist moxonidine (Fairbanks and Wilcox, 1999). Furthermore, intrathecally administered $\alpha_{2 C}$ antisense oligodeoxynucleotides decreased mechanical antinociception induced by clonidine and other antinociceptive agents in the rat, suggesting that the $\alpha_{2 \mathrm{C}}$ subtype is also involved in antinociception; however, confirmatory evidence that expression of only the $\alpha_{2 \mathrm{C}}$ subtype was decreased was not provided (Aley and Levine, 1997). It should be acknowledged that studies on genetically modified reagents may provide misleading information. In the case of the knock-out models, these animals not only lack the protein of interest but the organisms have had an opportunity to adapt to this deficiency during their development. These putative adaptive responses to the knock-out remain largely undocumented.

Whereas the $\alpha_{2 \mathrm{~B}}$ adrenergic receptor subtype has been found to mediate some physiological responses (Link et al., 1996), its role in antinociception has not been previously established using transgenic animals. In the rat spinal cord and dorsal root ganglion, mRNA for the $\alpha_{2 \mathrm{~A}}, \alpha_{2 \mathrm{~B}}$ and $\alpha_{2 \mathrm{C}}$ subtypes have been identified; in the spinal cord $\alpha_{2 \mathrm{~A}}$ mRNA is abundant in lamina I, II, and V, whereas the $\alpha_{2 \mathrm{C}}$ exhibit a weaker and less distinct signal throughout the dorsal horn, and the $\alpha_{2 \mathrm{~B}}$ are occasionally seen in lamina II (Zeng and Lynch, 1991; Nicholas et al., 1993; Shi et al., 1999). In the dorsal root ganglia, mRNA for the $\alpha_{2 \mathrm{C}}$ subtype predominates ( $80 \%$ of neuron profiles), whereas $\alpha_{2 \mathrm{~A}}$ are seen in $\sim 20 \%$ of neurons, and the $\alpha_{2 \mathrm{~B}}$ mRNA is found only in small numbers of neurons (Nicholas et al., 1993; Cho et al., 1997; Gold et al., 1997; Shi et al., 2000). However, the low prevalence of $\alpha_{2 \mathrm{~B}}$ mRNA in the rat spinal cord and dorsal root ganglion may not necessarily reflect a lack of functional importance (Nicholas et al., 1996).

We have demonstrated that there is a robust signal for $\alpha_{2 \mathrm{~B}}$ mRNA in the spinal cord of mice. One possible site at which this receptor subtype may play a role in antinociception may be at the level of the GABAergic interneurons in lamina III; these interneurons have long been known to have a role in descending inhibition (Willis et al., 1997). It is notable that a strong signal for $\alpha_{2 \mathrm{~B}}$ mRNA has been detected in lamina $\mathrm{I}-\mathrm{V}$ in the spinal cord of humans (Smith et al., 1995) and that $\alpha_{2}$ adrenoceptors in this region are upregulated after spinal cord transection (Giroux et al., 1999), suggesting that these may be coupled to descending inhibitory pathways.

Finally, the data from these studies indirectly refute the "unitary hypothesis for anesthetic action." In this study we provide clear evidence that the sedative and the antinociceptive actions of $\mathrm{N}_{2} \mathrm{O}$ appear to be mediated by different molecular mechanisms. Whereas the antinociceptive response clearly requires the participation of both noradrenergic pathways and $\alpha_{2 \mathrm{~B}}$ adrenoceptors, neither mechanism is needed for the hypnotic-sedative action of $\mathrm{N}_{2} \mathrm{O}$. Therefore, we posit that not only are different anesthetic agents not acting via the same mechanism, but the same anesthetic compound transduces different aspects of the anesthetic state at different sites.

\section{REFERENCES}

Aley KO, Levine JD (1997) Multiple receptors involved in peripheral alpha 2, mu, and A1 antinociception, tolerance, and withdrawal. J Neurosci 17:735-744.

Altman JD, Trendelenburg AU, MacMillan L, Bernstein D, Limbird L, Starke K, Kobilka BK, Hein L (1999) Abnormal regulation of the sympathetic nervous system in alpha2A-adrenergic receptor knockout mice. Mol Pharmacol 56:154-161.

Bylund DB, Eikenberg DC, Hieble JP, Langer SZ, Lefkowitz RJ, Minneman KP, Molinoff PB, Ruffolo RR, Trendelenburg U (1994) International union of pharmacology nomenclature of adrenoceptors. Pharmacol Rev 46:121-135.

Byrum CE, Stornetta R, Guyenet PG (1984) Noradrenergic projections to all regions of the spinal cord arise almost entirely from the dorsolateral pontine catecholamine cell groups the locus coeruleus (LC), A5 and A7 that all play a role in antinociception. Brain Res 303:15-29.

Cho H-J, Kim D-S, Lee N-H, Kim J-K, Lee K-M, Han K-s, Kang Y-N, Kim K-J (1997) Changes in the alpha2-adrenergic receptor subtypes gene expression in rat dorsal root ganglion in an experimental model of neuropathic pain. NeuroReport 8:3119-3122.

Chomczynski P, Sacchi N (1987) Single-step method of RNA isolation by acid guanidinium thiocyanate-phenol-chloroform extraction. Anal Biochem 162:156-159.

Clement CI, Keay KA, Bandler R (1998) Medullary catecholaminergic projections to the ventrolateral periaqueductal gray region activated by halothane anesthesia. Neuroscience 86:1273-1284.

Fairbanks CA, Wilcox GL (1999) Moxonidine, a selective alpha2adrenergic and imidazoline receptor agonist, produces spinal antinocicieption in mice. J Pharmacol Exp Ther 290:403-412.

Fender C, Fujinaga M, Maze M (2000) Strain differences in the antinociceptive effect of nitrous oxide on the tail flick test in rats. Anesth Analg 90:195-199.

Giroux N, Rossignol S, Reader TA (1999) Autoradiographic study of alpha1- and alpha2-noradrenergic and serotonin1a receptors in the spinal cord of normal and chronically transected cats. J Comp Neurol 406:402-414.

Gold MS, Dastmalchi S, Levine JD (1997) Alpha-2 adrenergic receptor subtypes in rat dorsal root and superior cervical ganglion neurons. Pain 69:179-190.

Graham BA, Hammond DL, Proudfit HK (1997) Differences in the antinociceptive effects of alpha-2 adrenoceptor agonists in two substrains of Sprague-Dawley rats. J Pharmacol Exp Ther 283:511-519.

Graham BA, Hammond DL, Proudfit HK (2000) Synergistic interactions between two alpha 2-adrenoceptor agonists, dexmedetomidine and ST91 , in two substrains of Sprague-Dawley rats. Pain 85:135-143.

Guo TZ, Poree L, Golden W, Stein W, Fujinaga J, Maze M (1996) Antinociceptive response to nitrous oxide is mediated by supraspinal opiate and spinal alpha 2 adrenergic receptors in the rat. Anesthesiology 85:846-852.

Guo TZ, Davies MF, Kingery WS, Patterson AJ, Limbird LE, Maze M (1999) Nitrous oxide produces antinociceptive response via alpha 2B and/or alpha 2C adrenoceptors subtypes in mice. Anesthesiology 90:470-476.

Hahn MK, Bannon MJ (1999) Stress-induced c-fos expression in the rat locus coeruleus is dependent on neurokinin 1 receptor activation. Neuroscience 94:1183-1188.

Hunter JC, Fontana DJ, Hedley LR, Jasper JR, Lewis R, Link RE, Secchi R, Sutton J, Eglen RM (1997) Assessment of the role of alpha2adrenoceptor subtypes in the antinociceptive, sedative and hypothermic actions of dexmedetomidine in transgenic mice. $\mathrm{Br} \mathrm{J}$ Pharmacol 122:1339-1344.

Jevtovic-Todorovic V, Todorovic SM, Mennerick S, Powell S, Dikranian K, Benshoff N, Zorumski CF, Olney JW (1998) Nitrous oxide (laughing gas) is an NMDA antagonist, neuroprotectant and neurotoxin. Nat Med 4:460-463.

Jones SL (1991) Descending noradrenergic influences on pain. Prog Brain Res 88:381-394.

Jordan LM (1998) Initiation of locomotion in mammals. Ann NY Acad Sci 16:83-93.

Kingery WS, Davies MF, Maze M (1997). Molecular mechanisms for the analgesic properties of alpha-2 adrenergic agonists. In: Molecular neurobiology of pain (Borsook D, ed) Vol 9, pp 275-304. Seattle: IASP.

Koblin DD, Dong DE, Eger EI (1979) Tolerance of mice to nitrous oxide. J Pharmacol Exp Ther 211:317-325.

Krukoff TL, Morton TL, Harris KH, Jhamandas JH (1992) Expression of $\mathrm{c}$-fos protein in rat brain elicited by electrical stimulation of the pontine parabrachial nucleus. J Neurosci 12:3582-3590.

Lakhlani PP, MacMillan LB, Guo TZ, McCool BA, Lovinger DM, Maze M, Limbird LE (1997) Substitution of a mutant alpha 2A-adrenergic receptor via "hit and run" gene targeting reveals the role of this subtype in sedative, analgesic, and anesthetic-sparing responses in vivo. Proc Natl Acad Sci USA 94:9950-9955.

Li C, Chen P, Smith MS (1999) Neural populations in the rat forebrain and brainstem activated by the suckling stimulus as demonstrated by cFos expression. Neuroscience 94:117-129.

Link RE, Desai K, Hein L, Stevens ME, Chruscinski A, Bernstein D, Barsh 
GS, Kobilka BK (1996) Cardiovascular regulation in mice lacking alpha 2-adrenergic receptor subtypes B and C. Science 273:803-805.

MacDonald E, Scheinin M (1995) Distribution and pharmacology of alpha 2-adrenoceptors in the central nervous system. J Physiol Pharmacol 46:241-258.

MacMillan LB, Hein L, Smith MS, Piascik MT, Limbird LE (1996) Central hypotensive effects of the alpha $2 \mathrm{~A}$-adrenergic receptor subtype. Science 273:801-803.

Martin WJ, Gupta NK, Loo CM, Rohde DS, Basbaum AI (1999) Differential effects of neurotoxic destruction of descending noradrenergic pathways on acute and persistent nociceptive processing. Pain 80:57-65.

Millan MJ (1992) Evidence that an alpha2A-adrenoceptor subtype mediates antinociception in mice. Eur J Pharmacol 215:355-356.

Millan MJ, Bervoets K, Rivet J-M, Widdowson P, Renouard A, LeMarouille-Girardon S, Gobert A (1994) Multiple alpha-2 adrenergic receptor subtypes. II. Evidence for a role of rat alpha-2A adrenergic receptors in the control of nociception, motor behavior and hippocampal synthesis of noradrenaline. J Pharmacol Exp Ther 270:958-972.

Miura M, Takayama K, Okada J (1994) Neuronal expression of Fos protein in the rat brain after baroreceptor stimulation. J Auton Nerv Syst 50:31-43.

Monnikes H, Lauer G, Bauer C, Tebbe J, Zittel TT, Arnold R (1997) Pathways of fos expression in locus coeruleus, dorsal vaga complex, and PVN in response to intestinal lipid. Am J Physiol 273:R2059-R2071.

Nicholas AP, Pieribone V, Hokfelt T (1993) Distributions of mRNAs for alpha-2 adrenergic receptor subtypes in rat brain: an in situ hybridization study. J Comp Neurol 328:575-594.

Nicholas AP, Hokfelt T, Pieribone VA (1996) The distribution and significance of CNS adrenoceptors examined with in situ hybridization. Trends Pharmacol Sci 17:245-254.

Ono H, Mishima A, Ono S, Fukuda H, Vasko MR (1991) Inhibitory effects of clonidine and tizanidine on release of substance $\mathrm{P}$ from slices of rat spinal cord and antagonism by alpha-adrenergic receptor antagonists. Neuropharmacology 30:585-589.

Paxinos G, Watson C (1986) The rat brain in stereotaxic coordinates, Ed 2. Sydney: Academic.

Presley RW, Menetrey D, Levine JD, Basbaum AI (1990) Systemic morphine suppresses noxious stimulus-evoked Fos protein-like immunoreactivity in the rat spinal cord. J Neurosci 10:323-335.

Rohde DS, Basbaum AI (1998) Activation of coeruleospinal noradrener- gic inhibitory controls during withdrawal from morphine in the rat. J Neurosci 18:4393-4402.

Shi T-JS, Winzer-Serhan U, Leslie F, Hokfelt T (1999) Distribution of alpha2-adrenoceptor mRNAs in the rat lumbar spinal cord in normal and axotomized rats. NeuroReport 10:2835-2839.

Shi T-JS, Winzer-Serhan U, Leslie F, Hokfelt T (2000) Distribution and regulation of alpha2-adrenoceptors in rat dorsal root ganglia. Pain $84: 319-330$.

Smith MS, Schambra UB, Wilson KH, Page SO, Hulette C, Light AR, Schwinn DA (1995) Alpha 2-adrenergic receptors in human spinal cord: specific localized expression of mRNA encoding alpha 2-adrenergic receptor subtypes at four distinct levels. Mol Brain Res 34:109-117.

Stone LS, MacMillan LB, Kitto KF, Limbird LE, Wilcox GL (1997) The alpha2A adrenergic receptor subtype mediates spinal analgesia evoked by alpha 2 agonists and is necessary for spinal adrenergic-opioid synergy. J Neurosci 17:7157-7165.

Takano M, Takano Y, Yaksh TL (1992a) The effect of intrathecally administered imiloxan and WB4101: possible role of alpha2-adrenoceptor subtypes in the spinal cord. Eur J Pharmacol 219:465-468.

Takano Y, Yaksh TL (1992b) Characterization of the pharmacology of intrathecally administered alpha-2 agonists and antagonists in rats. J Pharmacol Exp Ther 261:764-772.

Takayama K, Suzuki T, Miura M (1994) The comparison of effects of various anesthetics on expression of Fos protein in the rat brain. Neurosci Lett 176:59-62.

West WL, Yeomans DC, Proudfit HK (1993) The function of noradrenergic neurons in mediating antinociception induced by electrical stimulation of the locus coeruleus in two different sources of Sprague-Dawley rats. Brain Res 626:127-135.

Willis WD, Westlund KN (1997) Neuroanatomy of the pain system and of the pathways that modulate pain. J Clin Neurophysiol 14:2-31.

Wrenn CC, Picklo MJ, Lappi DA, Robertson D, Wiley RG (1996) Central noradrenergic lesioning using anti-DBH-saporin: anatomical findings. Brain Res 7401:175-184.

Zeng D, Lynch KR (1991) Distribution of alpha2-adrenergic receptor mRNAs in the rat CNS. Mol Brain Res 10:219-225.

Zhang C, Davies MF, Guo TZ, Maze M (1999) The analgesic action of nitrous oxide is dependent on the release of norepinephrine in the dorsal horn of the spinal cord. Anesthesiology 91:1401-1407. 